\title{
İslâm Eğitim Geleneğinde Bilginin Üretim, Paylaşım ve Dolaşım Kültürü Üzerine Bazı Değerlendirmeler
}

\section{Some Assessments on the Culture of the Production, Sharing and Circulation of Knowledge in Islamic Educational Tradition}

\section{Fatih İpek}

Arş.Gör.Dr., Necmettin Erbakan Üniversitesi, Ahmet Keleșoğlu İlahiyat Fakültesi, Din Eğitimi Anabilim Dall

Res. Assist. PhD, Necmettin Erbakan University, Ahmet Keleşoğlu Faculty of Theology, Department of Religious Education

Konya / Turkey

fatihipek01@gmail.com | https://orcid.org/0000-0001-8995-1846

Article Type / Makale Tipi

Research Article / Araștırma Makalesi

DOI: $10.33420 /$ marife.1009167
Article Information / Makale Bilgisi

Received / Gelis Tarihi: 13.10.2021

Accepted / Kabul Tarihi: 29.11.2021

Published / Yayın Tarihi: 30.12.2021

Cite as / Atıf: İpek, Fatih. "İslâm Eğitim Geleneğinde Bilginin Üretim, Paylaşım ve Dolaşım Kültürü Üzerine Bazı Değerlendirmeler". Marife 21/2 (2021): 749-775.

https://doi.org/10.33420/marife.1009167

Plagiarism / Intihal: This article has been reviewed by at least two referees and scanned via a plagiarism software. / Bu makale, en az iki hakem tarafindan incelendi ve intihal içermediği teyit edildi.

\section{(c) (1) $(\Theta$}

Copyright / Telif Hakku: "This article is an open access article distributed under the terms and conditions of the Creative Commons Attribution-NonCommercial-NoDerivatives 4.0 (CC BY-NC-ND 4.0) International License." / "Bu makale Creative Commons Alıntı-GayriTicari-Türetilemez 4.0 (CC BY-NCND 4.0) Uluslar arası Lisansı altında lisanslanmıştır." 


\section{İslâm Eğitim Geleneğinde Bilginin Üretim, Paylaşım ve Dolaşım Kültürü Üzerine Bazı Değerlendirmeler}

\section{Özet}

İslâm eğitimi, temelde İslâm dininin ana kaynaklarının ilke ve öğretileri etrafinda oluşmuş ve Müslümanların tarihi tecrübeleriyle harmanlanarak devam edegelen bir geleneğe sahiptir. Her gelenek gibi hem statik hem de dinamik bir yapısı olan İslâm eğitim geleneği çekirdek kısmı değişmeden kabuk kısmı sürekli yenilenen bir gelenek olarak çok geniş boyutlardaki dinsel, düşünsel ve kültürel birikimlerden süzülerek olușmuștur. Böylece İslâm eğitim geleneği farklı epistemolojik ve pedagojik teorileri kendine özgü bir biçimde barındıran bir gelenek olarak geleceğe yolculuğunu sürdürmüștür. İslâm eğitiminin bu zengin birikiminden faydalanmak adına bu birikimin eğitimsel açıdan detaylı bir biçimde ele alınması gerekmektedir. Kuşkusuz "bilgi"ye ait konular bu incelemelerde başı çeken konulardan olmalıdır.

Bu çalışmanın konusu İslâm eğitim geleneğinin bilgi üretim, paylaşım (öğrenme-öğretme) ve dolaşım kültürünü niteliksel açıdan tartışmaktır. Çalıșmanın cevap aradığı temel soru: "İslâm eğitim geleneğinde bilginin üretimi, paylaşımı ve dolaşımı açısından nasıl bir kültürün hâkim olduğu" sorusudur. Doküman taraması yöntemiyle tespit edilen örneklerle İslâm eğitim geleneğinin bilgi/bilgilenme kültürünün bazı açılardan eğitimsel değerinin tartıșılması amaçlanmıștır. Bu amaç gerçekleștirilirken aynı zamanda İslâm eğitim geleneği için dile getirilen bazı olumsuz iddialar da ele alınmıştır. Bahsi geçen iddialar; İslâm eğitiminin dogmatik, tek tipleştirici, ezberci ve harici otorite merkezli olduğu iddialarıdır.

Her ne kadar bu iddialara cevap verilirken daha çok İslâm eğitimin beslendiği teorik çerçeveden hareket edilmiş olsa da İslâm eğitiminde teoriler ve uygulamalar arasında önemli farklılıkların ortaya çıktığı gerçeği göz ardı edilmemiștir. Farklı bir çalıșmanın konusu olacağı fikrinden hareketle bu çalışmada İslâm eğitim geleneğinin beslendiği ana kaynaklardan (Kur'an ve sünnet) referans verme yoluna gidilmemiştir. Çalışmanın ana referans çerçevesi İslâm eğitiminin geleneksel yapısı ve uygulamaları üzerine olan literatür ile sinırlandırılmıştır.

Çalışmanın sonucunda literatürdeki verilere göre İslâm eğitim geleneğinde hâkim olan bilgi/bilgilenme kültürünün katı bir dogmatizmle ve tektiplilik ile uyumlu olmadığı, sadece bilginin aktarımına dayanmadığı görülmüștür. Bilgiyi tartışarak değerlendirmenin ve bilgiye eleștirel olarak yaklaşmanın bu kültürde belirgin bir biçimde teşvik edildiği tespit edilmiştir. Coğrafyaya, zamana ve diğer şartlara göre farklı müfredatın ve farklı kaynak metinlerin tercih edilmesine bağlı olarak dolaşımda olan bilgi birikiminin de yer yer farklılıklar arz ettiği görülmektedir. Hem İslâm dünyasının farklı coğrafyalarında hem de aynı Müslüman toplum içerisinde eğitimin yapısal ve davranıșsal boyutlarının değișmesi, İslâmi eğitim geleneği için "tektiplilik" ya da "tektipleștirici" iddiasının doğru olamayacağına işaret etmektedir. İslâm eğitiminde "ezberleme" önemli bir yer kaplasa da hiçbir zaman anlama eyleminden koparılmamış, sadece bilginin nakline dayanan mekanik bir öğrenme şekli olarak görülmemiştir. Ezberleme etkinliğinin öncelenmesi, bu geleneğin ezberci eğitim anlayıșına sahip olduğunu göstermemektedir. Bunun yanı sıra bu geleneğe özgü olarak "çok disiplinli uzmanlaşmanın" oldukça yaygın olduğu görülmektedir. Ana disiplin uzmanlığından önce farkl disiplinlerde uzman olmak, müslüman bilginlerini, önemli bir oranda, sadece tek bir disiplinin kuralları çerçevesinde bilgi üretme zorunluluğundan kurtarmıştır. Ayrıca araștırmanın bulgularına göre İslâm eğitim geleneğinde "ilmi saygınlı" ve "akademik özgürlük" kavramları etrafında olușan bilgilenme kültürünün siyasal ve epistemik otoritelerin bilgi üretimine ve dolaşımına gelişigüzel müdahalelerini engellediği söylenebilir.

İslâm eğitim geleneğinin bilgi/bilgilenme kültürü bugünkü eğitim anlayışımıza ve uygulamalarımıza katkı sunacak önemli veriler barındırmaktadır. Bu veriler Müslümanların eğitimle ilgili bazı problemlerini çözmeye ışık tutabilir. Müslümanların çağdaş eğitim karşısında yaşadığı uyumsuzlukların ve krizlerin aşılması için İslâm eğitim geleneğini farklı bakış açılarıyla ve farklı boyutlarıyla değerlendiren çalıșmalar yapılmalıdır.

Anahtar Kelimeler: Din Eğitimi, İslâm Eğitimi, Dogmatik Eğitim, Tektipleștirici Eğitim, Akademik Özgürlük 


\section{Some Assessments on the Culture of the Production, Sharing and Circulation of Knowledge in Islamic Educational Tradition}

\section{Summary}

Islamic education has a tradition that is formed around the principles and teachings of the main sources of Islam and blended with the historical experience of Muslims. The Islamic education tradition, which has both a static and dynamic structure like every tradition, has been formed as a result of filtering from a wide range of religious, intellectual, and cultural accumulations whose core part has not changed and whose shell is constantly renewed. Thus, the Islamic education tradition continued its journey into the future as a tradition that contains different epistemological and pedagogical theories in its unique way. To benefit from the rich legacy of Islamic education, one should deal with it comprehensively in terms of education. Undoubtedly, the issues of "knowledge" should be among the most prominent subjects of these studies.

The subject of this paper is to discuss the knowledge production, sharing(learning-teaching), and circulation culture of Islamic education in terms of quality. The main question of this paper is: "What kind of culture dominated the Islamic tradition of education in terms of the production, sharing, and circulation of knowledge". It aims to discuss the educational value of the knowledge culture of Islamic education in some respects through the examples selected via the document analysis method. While realizing this purpose, it will discuss some negative claims about the Islamic education tradition. The aforementioned claims, namely, Islamic education is dogmatic, stereotyping, based on memorization, and external authority-centered.

While responding to these claims, the fact that there are important differences between theories and practices in Islamic education has not been overlooked, although the theoretical framework in which Islamic education is fed has been taken into consideration. Based on the idea that it will be the subject of a different study, in this article, reference is not made to the main sources from which the Islamic education tradition is fed, namely the Quran and the Sunnah. The mainframe of reference of the study is often limited to the literature on the traditional structure and practices of Islamic education.

At the end of the research, it has been seen that according to the data in the literature, the culture of learning, dominant in the Islamic education tradition is neither compatible with strict dogmatism and uniformity nor it is based only on knowledge transfer. It is found that evaluating knowledge by discussing and approaching information critically is encouraged in this culture. Depending on the preference of different curricula and sources according to geography, time, and other conditions, it is seen, the circulating knowledge also differs occasionally. The fact that education changes in structural and behavioral dimensions both in different geographies of the Islamic world and the same Muslim society indicates that the claim of "uniformity" or "stereotyping" cannot be justified for Islamic education. Although memorization occupies an important place in Islamic education, it has never been seen as a form of mechanical learning based on the transmission of knowledge and separated from the act of understanding. Prioritizing the memorization activity does not indicate that this tradition has a rote learning approach. In addition, within this tradition, "multidisciplinary specialization" appears to have been common. Specialization in different disciplines before the main discipline of expertise would save Muslim scholars, to an important extent, from the limitation of producing knowledge in the framework of a single discipline. Moreover, according to the findings of the research, it can be said that the culture of learning formed around the concepts of "scientific dignity" and "academic freedom" in Islamic education prevents the arbitrary interventions of political and epistemic authorities in the production and circulation of knowledge.

The knowledge/information culture of the Islamic education tradition has important outputs that will contribute to our current understanding of education and its practices. These outputs can shed light on solving some of the problems of Muslims regarding education. To overcome the incompatibilities and crises experienced by Muslims in the face of contemporary education, studies should be conducted that evaluate different aspects of the Islamic education tradition from different perspectives.

Keywords: Religious Education, Islamic Education, Dogmatic Education, Stereotyping Education, Academic Freedom 


\section{Giriş}

İslâm eğitimi kavramı farklı yazarlar tarafından farklı anlamlarda kullanılmaktadır. Bu kavram hem bir eğitim anlayışını, hem eğitim sürecinin karakterini hem de bir din olarak bizzat İslâm'ın öğretilmesini ifade etmek için kullanılmıştır. Bu çalışmada ise "İslâm eğitimi" kavramı ile "İslâm'ın ilke ve öğretilerine dayalı her türlü öğretme ve öğrenme" (Tan, 2011, 4) kastedilmektedir. Bu doğrultuda İslâm eğitim geleneği, temelde İslâm dininin ana kaynaklarının ilke ve öğretileri etrafında oluşmuş ve Müslümanların tarihi tecrübeleriyle harmanlanarak devam edegelen bir gelenek olarak tanımlanabilir. Bu geleneğin başlangıç noktası teorik olarak, ilk insan ve ilk peygamber olması hasebiyle, Hz. Âdem'e dayansa da pratikte Müslümanların eğitim geleneğini ifade etmesi açısından H. Muhammed (s.a.v.)'e gelen ilk vahye dayanmaktadır.

Tarihi süreçte birçok din, kültür ve medeniyetle ilişkiye girerek gelişen İslâm medeniyetinin eğitim geleneği de bu ilişkilerin ve değișen zamanın şartları gölgesinde gelişmeye devam etmektedir. İslâm dininin "ötekinin yaşatılmasına saygı" olarak ifade edebileceğimiz anlayışını muhafaza ederek çok geniş bir coğrafyaya yayılması, Müslümanların başka inanç ve kültürlerle olan ilişkisinde çeşitliliğe ve sürekliliğe neden olmuştur. Bahsi geçen bu çeșitlilik ve süreklilik, İslâm medeniyetinin bütün unsurlarına yansıdığı gibi onun eğitim geleneğine de yansımıştır. $\mathrm{Bu}$ açıdan çekirdek kısmı değişmeden kabuk kısmı sürekli yenilenen bir gelenek olarak İslâm eğitim geleneğinin çok geniş boyutlarda dinsel, düşünsel ve kültürel birikimlerden süzülerek oluștuğu ve her gelenek gibi onun da hem statik hem de dinamik bir yapıya sahip olduğu söylenebilir.

Hz. Peygamber döneminden itibaren, karşılaştığı kültürlerin birikimlerini kullanan ve kendi birikimini de o kültürlere aktarmayı başaran İslâm eğitim geleneği 18. yüzyıldan sonra (1699 Karlofça Antlaşması'ndan sonrası) farklı bir seyirde devam etmiştir. Batıya olan üstünlüğün kaybedilmesi dikkatleri eğitilmiş insan unsuruna dolayısıyla da Müslümanların eğitim geleneğine çekmiştir. İslâm eğitim geleneği yapı, müfredat, nitelik vb. açılardan derinden sorgulanarak Batı eğitimi ile mukayese edilmiștir (Tan, 2015, 3-5; Lewis, 2020, 27-29). Bu mukayeselerin sonucunda İslâm eğitimi ile batı eğitimini birbirinden üstün gören yorumların yanı sıra bu iki eğitim geleneğini uzlaştırmaya çalışan yorumlar ortaya çıkmıştır. Bilhassa batı eğitim anlayışını İslâm eğitim anlayışından daha ileri seviyede gören yorumcuların bir takım iddiaları İslâm eğitim anlayışıyla ilgili bazı olumsuz yaftalamalara neden olmuştur. "Dogmatik ve tek tipleştirici olma; ezberci karakterde olma; orijinal bilgi üretememe; otorite merkezli bilgi aktarımına dayalı olma" gibi iddialar bunlardan bazılarıdır (bk. Halstead, 2004; Tan, 2011; a.mlf., 2015).

Bilginin üretilmesi, paylaşılması, değerlendirilmesi, düzenlenmesi ve yeniden üretilmesi süreçleri bir döngü halinde devam eden süreçlerdir. Bilgilenme süreci olarak da tanımlanabilecek bu döngünün eğitimsel ve düşünsel boyutları kadar, yönetimsel ve toplumsal boyutları da bulunmaktadır. $\mathrm{Bu}$ açıldan bilgi/bilgilenme olgusunun süreçleri eğitim bilimleri, felsefe, psikoloji, sosyoloji ve siyasal bilimlerin ortak çalışma alanını oluşturmuş̧tur. Bahsi geçen bu çok boyutluluktan dolayı bilginin üretimi, kullanımı, paylaşımı, değerlendirilmesi vb. süreçle- 
rin gruplar, topluluklar veya toplumlar açısından bir şekilde kesintisiz devam eden bir kültürü/anlayışı oluşturduğu söylenebilir. "Bilgi veya bilgilenme kültürü" olarak ifade edilebilecek bu kültür, epistemolojiye ait bütün kabullerin ve varsayımların açık veya örtük bir uzlaşıyla nesiller boyu paylaşılmasını ifade etmektedir. İslâm eğitim geleneği incelendiğinde Müslüman toplumlar için de bahsi geçen bir çeşit bilgilenme kültürünün var olduğu görülmektedir.

Tamdoğan Gürdal (2004) "bilgi kültürü” veya "bilgilenim kültürü” kavramını "bireyin ve/veya toplumun bilgiyi kendi düzeyinde -gereksinimleri, algılayış, anlayış, kavrayış biçimlerini ve yoğunluğunu içeren- "yaşayış" durumu" olarak açılklamaktadır. Ona göre bilgi ve/veya bilgilenim kültürü kavramı bilginin bireysel ve toplumsal açıdan taşıdığı "değere" ve "kendine özgülüğe" işaret etmektedir. Bu durumda İslâm medeniyetinin bilgiye ait bütün tasavvurları, kabulleri ve varsayımları İslâm eğitim geleneğinin kendine özgü bilgi/bilgilenme kültürünü oluşturmaktadır.

İslâm eğitim geleneğinde farklı epistemolojik teorilerin yeri geldiğinde "maksimum fayda prensibi"ne göre birlikte var olduğu görülmektedir. Bu durum da İslâm eğitim geleneğinin kendine özgü bilgi anlayışının olduğunu söylemenin daha doğru olacağını göstermektedir. Epistemolojide kendine özgü bu entelektüel gelenek, Kutluer $(2006,51)$ 'in ifadesiyle "hem yineleme hem yenilenme kabiliyeti" olan bir gelenektir. İslâm eğitiminin kendine özgü olan bilgi anlayıșı, bazı istisnai uygulamalar hariç tutulmak kaydıyla, İslâm eğitiminin geleneksel yapısına ve uygulamalarına belirgin bir şekilde yansımaktadır. Bu durumda İslâm eğitim geleneğindeki bilgi/bilgilenme kültürünün de farklı epistemolojik ve pedagojik teorileri barındıran kendine özgü bir yapıya sahip olduğu söylenebilir.

\section{Araştırmanın Problemi, Amacı ve Önemi}

İslâm eğitim geleneğine hâkim olan bilgilenim biçiminin ve kültürünün ne olduğunu daha net bir biçimde ortaya koyabilmek eğitim mirasımızdan daha verimli faydalanabilmek açısından oldukça önemlidir. İslâm medeniyet tarihinde iktisadi, bilimsel, toplumsal ve sanatsal açıdan hem oldukça parlak dönemlerin yaşandığı hem de bunun aksi dönemlerin yaşandığı yadsınamaz bir gerçektir. Kuşkusuz bahsi geçen parlak dönemlerin yaşanmasında eğitim anlayışının ve uygulamalarının rolü büyük olmuştur. Aynı şekilde İslâm medeniyetinde duraklama ve bozulma dönemlerinin yaşanmasında da eğitim alanına ait sorunlar başrol oynamıştır. Bu açıdan hem geçmişin hazinesinden yaralanmak adına hem de geçmişin hatalarından uzak durma adına İslâm eğitim geleneği üzerine yapılan çalışmalar önem arz etmektedir.

$\mathrm{Bu}$ çalışmada; İslâm medeniyetinin ilerleme vasıtalarından birinin bu medeniyete hâkim olan bilgi kültürünün olduğu fikrinden hareket edilmiştir. Çalışmamızda doküman incelemesi yöntemiyle alanyazındaki çalışmalardan ve İslâm eğitim geleneğindeki uygulamalardan hareketle belli açllardan İslâm eğitim geleneğindeki bilgilenim süreci ve kültürü ele alınmıştır. Bilginin üretilmesi, paylaşılması, aktarılması, değerlendirilmesi gibi süreçler açısından bilginin dolaşımı üzerine analizler yapılmaya çalışılmıştır. Elbette bütün bunlar yapılırken İslâm eğitim 
geleneğinin bütün yönleriyle incelendiği iddiasında bulunmak bu hacimde bir çalışmanın iddiası olamayacaktır. Bu çalışmada bahsi geçen bilgilenme süreci ve kültürü bilgi-otorite ilişkisi, orijinal bilgi üretme kapasitesi, bilgiyi üretme ve paylaşma faaliyetlerinin niteliği açısından yapılan değerlendirilmelerle sınırlandırılmıştır. Böylece literatürde bahsi geçen konulara dair tespitler ve değerlendirmeler tartışılarak bugünkü eğitim anlayışımıza ve uygulamalarımıza olumlu katkı sunacak verilere ulaşmak amaçlanmıştır. Bunun yanı sıra bu çalışmada İslâm eğitim geleneğinde bilgilenme sürecinin karakteri ve yapısı ile ilgili dile getirilen bazı olumsuz iddiaların (ezbercilik, dogmatiklik, tektiplilik vb.) tartışılması da amaçlanmiştır.

Bilgi ve bilgilenim kültürünü özel olarak ele almasa da alanyazında İslam eğitim geleneğinde bilgi teorilerine yer veren birçok çalışma bulunmaktadır. İslam eğitim geleneği alanında yapılan genel çalışmalarda ve dinî ilimler alanında yapılan özel çalışmalarda kaçınılmaz olarak epistemolojiye ilişkin konularda ele alınmıştır. Tan (2011)'ın "Islamic Education and Indoctrination: The Case in Indonesia" adlı çalışmasının ve Sahin (2013)'in “New Directions in Islamic Education: Pedagogy and Identity Formation" adlı çalışmasının teorik kısımları İslam eğitim anlayışında "doktrinerlik", "eleştirel düşünce", "orijinal bilgi üretme" meseleleri etraflıca ele alınmıştır. Ülkemizde ise Gözütok (2019)'un "İslam Medeniyetinin Eğitim Felsefesi” adlı çalışmasında İslam eğitim geleneğinde bilgi-iktidar ilișkisi, bilginin üretiminde ve paylașımında objektif ve sübjektif tutumlar ele alınmıștır. Bu açıdan çalışmamızın İslam eğitim geleneğinde bilgi üretiminin (orjinallik, bilmsel özgürlük, bilimsel saygınlık vb. açılardan) ve bilgi paylaşımının (ezbercilik, tektiplilik, eleștirellik vb. açılardan) niteliğiyle ilgili daha derli toplu bir tablo ortaya koymaya çalıștığı söylenebilir.

\section{2. İslâm Eğitim Geleneğinde Bilgilenme Sürecinin ve Kültürünün Analizi}

Bilginin doğasına ilişkin varsayımlar ve bilgiyi edinme süreçlerinin işleyiş biçimleri etrafında bir çeşit bilgi/bilgilenme kültürü oluşmaktadır. İslâm medeniyetinin bilgi kültürü İslâm'ın ana ilke ve öğretileri etrafında oluştuğu gibi İslâm'ın varlık, bilgi, estetik ve siyasi görüşünü yani müslümanların "dünya görüşünü" de yansıtmaktadır. İslâm eğitim geleneğinin bilgi kültürünü tanımak büyük emekli bir uğraş gerektirmektedir. Ancak bu kültürde; bilgi-otorite ve öğretmen-öğrenci ilişkisinin nasıl olduğu; dogmatik ve tektipleștirici bir eğitimin olup olmadığı; ilmi faaliyetlerin özgürce yapılıp yapılmadığının tespiti bu kültürü büyük oranda tanımayı kolaylaştıracaktır.

\subsection{Bilgi-İktidar İlişkisi, Tektiplilik ve Dogmatiklik Meseleleri Açısından}

İslâm eğitim geleneğinin yapılanma ve uygulama boyutunda epistemik otorite seçimini ve bilgi-iktidar ilişkisini incelemek bu geleneğin bilgi kültürünü tanımayı kolaylaștıracaktır. Bu açıdan İslâm eğitim geleneğinde bilgi iktidar ilișkisiyle ilgili siyasi gelişmelerin İslâm medeniyetinin eğitim politikalarına yansımasını incelemek önem arz etmektedir. Zira tarih boyunca İslâm devletlerinde çeşitli sebep- 
lerden dolayı farklı mezhepler resmi mezhep olarak seçilmiş ve aynı anda birden fazla rakip halife iş başında bulunabilmiştir. Bir veya birkaç mezhebin resmi mezhep olarak tercih edilmesi ve en üst yönetimsel otorite olarak farklı halifelere biat edilmesi, takip edilen eğitim politikalarını doğrudan veya dolaylı olarak etkilemiştir.

İslâm tarihinde dönemsel şartlar ve ihtiyaçlar farklı mezhepleri ön plana çıkarabilmiştir. Baskın olan ya da ön plana çıkan mezheplerin değişimi oldukça dinamik bir süreç olarak cereyan etmiştir. Şartlar ve ihtiyaçlar nakilci ve akılcı yönelimlere de yön vermiștir. Abbasilerin Mani dini ve Zerdüştlük ile mücadele ederken ön plana çıkarttığı Mu'tezilî eğitimin zamanla terkedilmesi bu duruma bir örnektir. Yönetimsel otorite anlamındaki bu hızlı değişimden dolayı İslâm dünyasında hiçbir zaman baskın bir biçimde belli bir grubun eğitim anlayışını yansıtan tek tip bir eğitim anlayışı görülmemiştir. Zira resmi mezheplerin ve halifeliğin el değiştirme hızı bahsi geçen baskınlığa müsaade etmemiştir. Kuşkusuz belli bir ekolü ya da belli bir anlayışı öne çıkarma teşebbüsleri olmuştur. Ancak ekoller ve anlayışların ön planda olmasıyla ilgili bahsi geçen ve oldukça hızlı seyreden döngü buna müsaade etmemiştir (bk. Gözütok, 2019, 180-185).

Bunun yanı sıra her dönemde resmi mezhebin dışındaki mezheplerin varlığını sorunsuz bir biçimde sürdürdüğü, diğer mezheplere uygun eğitim yapılmasının problem oluşturmadığı görülmektedir. Gözütok $(2019,185)$ 'un işaret ettiği gibi bu serbestlik sayesinde aynı medresenin çatısı altında farklı mezheplere göre eğitim yapılabilmiştir. Ayrıca itikâdi ve ameli olarak birbirini destekleyen mezheplerin aynı anda tercih edilmediği görülmüştür. Hanefîliği benimseyen Osmanlı medreselerinde Mâtürîdî kelâmına ait eserler yerine Eş'arî kelâm eserlerinin okutulması bu duruma güzel bir örnektir.

İslâm tarihinde siyasi otoritenin görüşlerinin kendi doğal ortamında kendi kaderini çizmesini takip etmek şeklindeki stratejisi ehli-sünnet inancını yerleştirme ya da batıl sayılan görüşleri yok etme konusunda da aynı olmuştur. Batıl sayılan inançlar şiddet eylemlerine dönüşmediği sürece genelde kamu eliyle bastırılmaya çalışılmamış, kendi doğal ortamında yok olması beklenmiştir. Kamunun müdahalesi ancak fitneye ve düzensizliğe sebebiyet veren ihtilaflar söz konusu olduğunda görülmüştür (Chamberlain 2014, 213-217). Orta Çağ'da Şam ve çevresi özelinde Chamberlain'ın yaptığı tespitleri doğrulayacak bir şekilde, mihne olayları gibi birkaç olayı dışarda tutmak kaydıyla, ortaçağ sonrasında da İslâm dünyasının büyük çoğunluğunda aynı seyri göstermiștir. "Bâtıl-hâk" ayrıșmasının dışındaki fikri ayrılıklar karşısında da kamu idaresi çoğunlukla hakem konumunda olmuş, bazı zamanlarda farklı görüşleri savunanlar bizzat idarecilerin huzurunda rahat bir şekilde tartışmıştır. Nitekim 17. yüzyıl Osmanlı devletinde IV. Murat döneminde Kadızâde-Sivâsî tartışmaları diye bilinen tartışmalar (tekke-medrese tartışmaları) bizzat padişahın huzurunda suhulet içerisinde yapılmıştır¹.

1 Ancak IV. Murat'ın ölümünden sonra gelen padișahların ve idarecilerin menfaate dayalı yanlı tutumları yüzünden her iki grup arasındaki tartışmaların kontrolden çıktığı dönemler olabilmiştir (bk. Gündoğdu, 1999). 
İslâm hukuku idaresinde galibiyet elde edemeyen "iktidar", bilgi-iktidar ilişkisi açısından eğitimin nesnesi olan bilgi üzerinde de galibiyet elde edememiştir. Hallaq (2020, 148-149)'göre Batı'nın aksine İslâm eğitim geleneğinde modern dönemin çok öncesinde, daha başlangıçta, bilgi-iktidar bağı koparılabilmiştir. Ona göre "biçimsel" olmasa da "esaslı" bir birliktelikten kendisini koparmıș olmasından dolayı İslam medeniyetinde Nietzsche, Foucault veya Gramsci’nin eleștirdiği gibi iktidar güdümünde bilgi üretimi söz konusu olmamıştır. Hallaq'ın işaret ettiği "biçimsel” ilişikinin (kadılık ve bazı bürokratik görevlendirmeler gibi) dışında İslâm akademik kültüründe iktidarla yakın ilişki içerisinde olan, iktidar güdümünde olan bir bilgin başta kendi meslektaşları tarafından ciddi bir biçimde eleştirilmiştir. Bu tarz bilginlerin ürettiği bilgiye daha çok şüpheyle yaklaşılmış, onların görüşleri daha sıkı bir değerlendirmeye tabi tutulmuştur. Nitekim Makdisi $(2007,284)$ de bu konuma düşmemek adına -bazı istisnalar dışında- çoğunlukla Müslüman bilginlerin iktidara yakın olmaktan çekindiğine dikkat çekmektedir. Bahsi geçen bu tutumdan dolayı İslâm eğitim geleneğinde bir şekilde bilgi iktidar ilişkisini düzenleyen, resmi olmayan mesleki bir iç denetim sisteminin kurulduğu izlenimini doğurmaktadır. Öyle ki, bu mesleki iç eleştiri sisteminin bilginlerin ürettiği bilgi üzerinde iktidar etkisini bertaraf edecek bir kontrol ve güvence sistemi haline geldiği söylenebilir.

İslâm eğitim geleneğinde bilgi-iktidar ilişkisi üzerine yapılan açlklamalardan hareketle Watt $(2017,172)$ 'ın “İslâm dünyasındaki birçok sıkıntının kaynağının hükümdarların aydınlar üzerindeki tahakkümünden ve aydınların hükümdarlara boyun eğmesinde kaynaklandığı" iddiasının tamamıyla doğru bir iddia olamayacağını söyleyebiliriz. Elbette tarihi süreçte İslâm dünyasında birçok kez âlimler üstünde hâkimiyet kurmak isteyen siyasi iradeler olmuştur. Bunun yanı sıra görüşlerini siyasi iradenin desteğiyle yayma eğiliminde olan bilginler de olmuştur. Ancak bunların nihai bir başarıya eriştiği, bilginlerin hükümdarlara koşulsuz boyun eğdiği söylenemez. Aksine Ebû Hanife, Ahmed bin Hanbel vb. örneklerinde olduğu gibi siyasi idarenin manipüle edilmiş bilgi üretme çabasına karşı koyma davranışı hem ilmi çevrelerde hem de kamuoyunda erdemli bir davranış olarak büyük takdir görmüştür. Bu bağlamda İbn Cemâa'nın Ebu'l Esved ed-Düeli'den naklen dile getirdiği "ilimden (bilgiden) daha değerli ve güçlü bir şey yoktur. Krallar (idareciler) halka egemendirler; âlimler ise krallara" $(1998,47)$ ifadesinin İslâm düşüncesinin ve eğitim anlayışının bilgi-iktidar ilişkisiyle ilgili genel yorumunu yansıttığı söylenebilir.

İslâm eğitim kurumlarının tarihinde siyasi otoriterin yanı sıra finansal otoritelerin de eğitim uygulamaları ve üretilen bilgiler üzerinde belirleyici bir rolünün olmadığı görülmektedir. Medrese ve vakıflarda finansal destekçiler hiçbir zaman bilginin üretiminde şekil verici bir konuma sahip olmamıştır. Bu kişiler vakıfların, eğitim kurumlarının kurulması ve yönetilmesi konusunda söz sahibi olmuşlar ancak bu kurumların yöneticileri arasında olmuş olsa dahi eğitim materyalinin seçimi ve öğretimin gerçekleştirilmesi konusunda söz sahibi olamamıştır. Hallaq (2020, 132)'ın vurguladığı gibi bilimsel merak ve uğraş, öğretimin hangi materyallerle ve nasıl yapılacağı konularında belirleyici unsur olmuştur. Nitekim İslâm coğrafyasında vakıfların sadece dînî saiklerle kurulmadığını, bazı seçkin ailelerin (âyân) 
kendi sosyal statülerini ve mal varlıklarını korumak gibi gizli amaçlar için de vakıf ve medrese kurduğunu iddia eden Chamberlain $(2014,74)$ dâhi âyânların etkisinden dolayı medreselerin ideolojik bir programa sahip olduğuna geçerli bir kanıtın olmadığını ifade etmektedir.

Makdisi $(2012,139)$ ve Berkey $(2015,77)$ de İslâm medeniyetinde yükseköğretimde zorlayıcı ve yönlendirici hâkim bir devlet politikası yerine bu kurumları destekçilerinin şekillendirdiğini ve bu durumun da İslâm eğitim geleneğinde yükseköğretimin tek tipleşmesini engellediği görüşünü savunmaktadır. Bu yazarların İslâm eğitim geleneğinde politik dış müdahalenin eğitim programını dolayısıyla da öğretimin nesnesi olan bilgiyi içermediği tespiti doğru bir tespit olmakla birlikte, eğitim kurumlarının tesisini ve devamını sağlayan destekçilerin müfredatta çeşitliliğe dolayısıyla düzensizliğe neden olduğu görüşü tartışmaya açık bir görüştür. Zira kutsal bir uğraş olarak görülen ilim uğraşı ve ilmi (gerçek bilgiyi) elde etme amacı kendisine devletlerin sınırları ötesinde ilmi saygınlığa dayalı bir varlık alanı oluşturmuştur. Zaman zaman bu saygınlık alanına nüfuz etme teşebbüsleri gösterilmiştir. Abbasîlerde mihne olayları, Emevîler'in Arap milliyetçiliğini ve Fâtımîler'in Şiî inancını öne çıkaran propaganda hareketlerindeki zorlayıcı uygulamaları bu teşebbüsler kapsamında değerlendirilebilir. Ancak bahsi geçen ilmi saygınlık alanı kendini bu müdahalelerden kurtarmayı bilmiştir. Siyasi otoriteler ya da finansal destekçiler bilginin üretiminde asli bir unsur olamamış, bu otoriteler ve destekçiler tarafından kabul görmüş bilgilerin öğretime dâhil edilmesi bir kriter olmamış, onların talepleri doğrultusunda bir bilginin öğretimin nesnesi olması söz konusu olmamıştır. Bu durumda bahsi geçen yazarların, "destekçilerin müfredata müdahalesi” ancak bazı destekçilerin eğitim kurumlarının kurulması esnasında maddi imkânlarını vakfederken belli ilimlerin okutulması, belli ilimlerde uzman yetiştirilmesi veya eğitim kurumunun müfredat yapısını ilerde değiştirecek düzenlemeleri engellemek istemesi gibi talepleriyle ilgili vakıf senetlerine koydukları kayıtlarla sinırlıdır. Bu kayıtlar Dârülhadis olarak kurulan bir kurumun Dârülkurra'ya dönüştürülmesinin engellenmesi gibi bir kayıt veya bir mezhebin fıkhının okutulmasının devamını sağlayan bir kayıttır ki bu durum zaten vakıf kültürünün ve işleyiş felsefesinin bizzat gerektirdiği bir durumdur. Bunun aksine finansal veya kamusal bir destekçinin müfredata veya derslerin içeriğine müdahalesi söz konusu olamamıştır.

İslâm medeniyeti eğitim tarihi açısından incelendiğinde eğitim kurumlarında bir mezhebin/bir ekolün ya da öğretilerine göre tektipleştirici bir eğitimin yapıldığı iddiası bazı açılardan doğru görünebilmektedir. Yüzeysel bir bakışla yapılan incelemeler bahsi geçen iddiaya kısmen doğruluk imkânı tanıyabilse de detaylı analizler "tektipli" ve "tektipleștirici" bir eğitimin İslâm eğitim anlayışıyla ilkesel olarak uyuşmayacağını göstermektedir. İslâm eğitim anlayışının tektipleştirici bir yaklaşıma sahip olamayacağı, en başta onun beslendiği ana kaynakların ilke ve öğretilerinden çıkartılabilir. Kur'an'da ve hadislerde ısrarlı bir biçimde akıl yürütmenin, tefekkür etmenin ve eleştirel bakabilmenin gereğinin vurgulandığı görülebilir. Bunun yanında İslâm medeniyetinde bilgilenme sürecinde kaynak, metot ve yaklaşım olarak bir çeşitliliğin olması, başlı başına bu eğitimin tektipleştirici olamayacağının önemli bir kanıtıdır. Zira İslâm düşüncesinde temelde bilgi kaynağı 
olarak akıl-nakil ayrımına dayanan farklı yaklaşımların farklı bilgilenme biçimini önceledikleri görülmektedir. Örneğin Câbirî (2001) ise İslâm kültürüne hâkim olan bilgi/bilgilenme sistemlerini; (1) beyânî bilgi sistemi, (2) irfânî bilgi sistemi ve (3) burhâni bilgi sitemi olarak listelemektedir. Kuşkusuz bilgi üretme/elde etme sürecinde bahsi geçen önceleme tercihi İslâm eğitiminin tektipleştirici karakterde olmasına müsaade etmemektedir.

Bütün bunlara rağmen Makdisi (2007; a.mlf., 2012) başta olmak üzere İslâm medeniyetindeki medrese eğitimi geleneği üzerine (bilhassa hukuk eğitimi üzerine) çalışan birçok yazar sadece bir ekolün öğretilerine göre kurulan ve işleyen (lonca sistemi benzeri olarak) medreselere dikkat çekmektedir. Farklı ekollerin bir arada eğitim gördükleri medreselere çok az dikkat çekilmektedir. İslâm tarihinde sadece bir fıkhî ekole göre eğitim yapılan vakıf medreselerinin yanında farklı ekollere göre eğitimin tek bir çatı altında yapıldığı medreseler de kurulmuştur. Melikşah, Nurettin Zengî ve Selahaddin Eyyûbî gibi hükümdarların yönetiminde İsfahan, Kahire ve Şam'daki medreselerde farklı mezheplerin aynı çatı altında eğitim yaptığı bilinmektedir (bk. Gözütok, 2019, 185). Abbasi halifesi MüstansırBillah'ın 13. yüzyılda Bağdat'ta kurdurduğu "Müstansıriyye" medresesi dört farklı mezhebin birlikte eğitime devam ettiği bir medresedir. Bu medresede toplanma salonuna açılan on iki kapının cennet kapılarını sembolize etmesi (bk. Dodge, 1962, 23) dört mezhebin dörde bölünmüş bir alanda öğretime devam etmesiyle birlikte düşünüldüğünde, sembolik bir mesajın verilmek istendiği izlenimi bırakmaktadır: Hakikate farklı yollardan ulaşmak isteyen, farklı yorumlara sahip Müslümanlar cennette bir arada bulunabilecektir.

Bütün İslâm coğrafyasının tek tip bir eğitim yapılanmasına ve uygulamalarına sahip olmadığını gösteren kanıtlardan biri de Endülüs Emevi devletindeki eğitimin serüvenidir. Endülüs'te eğitim başlangıçta İslâm dünyasının diğer bölgeleriyle büyük oranda benzeșen bir eğitim sistemine sahip olsa da Müvahhidîler döneminde köklü bir eğitim reformu hareketine girișmiştir. Bu harekete girișmenin ana tetikleyici unsuru ise taklîdi aşarak kendi orijinal eğitim sistemine geri dönmektir. Bağımsız ve özgün bir eğitim politikasının takip edilmesiyle bu hedef gerçekleştirilmiş ve Endülüs'te felsefenin ve özgür düşüncenin etkin olduğu bir eğitim alanı oluşturulmuştur (bk. Gözütok, 2019, 185). Yine Endülüs özelinde İslâm coğrafyasında tek tip eğitim yapılanmasının ve müfredatının geçerli olmadığının bir diğer kanıtı da İbn Haldûn (2004)'un kendi dönemimde Kuzey Afrika ve Endülüs'teki medreselerin müfredatını doğu medreseleri ile karşılaştırarak yaptığı eleştirilerdir.

İslâm eğitim geleneğinde coğrafyaya, zamana ve diğer şartlara göre farklı müfredatın tercih edilmesi bağlamında, eğitim materyali olarak kaynak metinlerin ve ders kitaplarının yer yer farklılık arz ettiği ve böylece farklı dolaşımda olan geçerli bilgi birikiminin de yer yer farklılıklar arz ettiği söylenebilir. Bu durum İslâm dünyasının farklı farklı coğrafyalarında ve topluluklarında değişme gösterdiği gibi aynı toplum içerisinde de değişme göstermiştir. Medreselerde okutulan metinler farklı dönemlerde benzerlik gösterseler de detaylı incelemeler her dönemde tercih edilen şerh ve hașiyelerin farklı olduğu metinlerin sürekli olarak güncellendiğini göstermektedir (bk. Furat, 2020, 86). Dolayısıyla İslâm eğitim geleneğinde zanne- 
dildiği gibi aynı bilginin aynı şekilde aktarımı ile devir daim eden bir eğitim yapılması söz konusu olmamaktadır. Bahsi geçtiği üzere eğitim kurumlarında, eğitimin hammaddesi olan bilgi hem zaman ve mekâna bağlı olarak hem de zaman ve mekândan bağımsız olarak değişim ve gelişim göstermiştir.

İslâm medeniyetindeki ilk ve orta dereceli okulların genelde benzer bir yapıya göre oluşturulduğu görüntüsü hâkim olsa da bu okullar aslında fiziki yapı, öğrenci profili, ekonomik imkânlar açısından çeşitlilik göstermektedir. Bunun yanında belli bir fıkhi mezhebi ve tasavvufi uygulamaları kabul etmeleri açısından da farklılaşma göstermektedir (Berkey, 2015, 17). Benzer bir durum yükseköğretimin yapıldığı medreseler için de söz konusudur. Medrese müfredatında tasavvufi öğretilerin tercihen kabul edilip edilmemesi, tercih edilen bilgi kaynağı ile ilgili bir çeşitliliği ortaya çıkarmaktadır. Bu durumda keşf, ilham, sezgi vb. bilgi kaynaklarının yer aldığı materyallerin bazı medreselerde öğretim sürecinde kullanıldığı, bazı medreselerin ise bu bilgi kaynaklarını dikkate almadığı söylenebilir. Şüphesiz bu farklılaşma bilginin elde edilmesi sürecinde metodolojik bir çeşitlilik oluşturduğu gibi bilginin yorumlanmasında ve üretilmesinde de bir çeşitlilik oluşturmaktadır. Bilhassa müderris şeyhler tarafından yönetilen ve medrese görevi de üstlenen tekkelerde bu durum daha net görülmektedir. Nitekim Osmanlı dönemi Sivasî ve Kadızade tartışmalarında bu çeşitliliğin tezahürüne rastlanılmaktadır (bk. Gündoğdu, 1999).

İslâm eğitim tarihinde Müslüman bilginlerin bilgi elde etmek için yaptığ yolculuklardan sıkça bahsedilmektedir. Önceleri hadis toplama faaliyetleri için yapılan ilim yolculukları (rihle) zamanla dinî ilimlerde ve diğer bilimlerde bilgi toplama amacı için de yapılmaya başlamıştır. Bir ilim dalında ya da bir konuda uzmanlığı ile tanınmış bir bilginle ilişkiye girmek mektuplaşma biçiminde yapıldığı kadar bizzat ziyaret ederek yüz yüze görüşme biçiminde de gerçekleşmiştir. Üstelik bu yolculuklar sadece bilgi elde etmek amacıyla yapılmamış, aynı zamanda mevcut bilgilerin doğruluğunun sınanması amacıyla da yapılmıștır. Sadece öğrencilere mahsus olmayan bu yolculukların mezheplerin kurucu imamları gibi tanınmış bilginler tarafından yapıldığı bilinmektedir. Müslümanların kurduğu imparatorlukların fiziki sınırları ve İspanya'dan Hindistan'a, Hicaz'dan Sibirya'ya kadar çok geniş bir coğrafyada Müslüman toplumların yaşadığı göz önüne alındığında bahsi geçen ilim yolculuklarının ne kadar büyük ölçekte olduğu anlaşlacaktır. $\mathrm{Bu}$ coğrafi ve kültürel genişlik durumu, İslâm Medeniyetinde üretilen bilginin ve bilimin oldukça kozmopolit bir yapıda olduğunu göstermektedir. Bu bağlamda bahsi geçen seyahatlerin bilginlere ve öğrencilere sağladığı fikirlerini ve bilgilerini sınama imkânının belli ölçüde onların sabit fikirli, katı dogmatik anlayışta olmasına ve eğitimin tektipleștirici olmasına engel olduğu söylenebilir.

Bauer (2019), İslâm medeniyetinin sanıldığından çok daha az dogmatikliğe sahip bir medeniyet olduğunu ifade etmektedir. Ona göre "Kur'an'ın yedi harf (k1raat) üzerine okunabilmesi" görüşünün Müslümanlar tarafından sorunsuzca benimsenmiş olması, en temel ve en dokunulmaz metin üzerinde kısmi de olsa okuyuş ve anlam çeşitliliğine müsaade edilmesi, bu kültürün olumsuz anlamda dogmatik bir anlayışa ve geleneğe sahip olmadığının göstergesidir. Bauer (2019)'in dikkat çektiği gibi bu durumun bir problem olarak görülmemesi, tefsirlerde okuyuş farklı- 
lıklarından kaynaklanan anlamlara çekinmeden yer verilmesi, İslâm eğitiminin epistemolojik temellerinin mutlak dogmacılığa dayanmadığını göstermektedir. Zira bir pedagojinin ve epistemolojinin sadece dogmaya dayanması onun varlığını sürdürmesini tehlikeye atmaktadır. Katı dogmacılık yeniliklerin ve değişimlerin karşısında dayanıklı olmadığı için insan için faydalılığı ve geçerliliği her geçen gün azalacaktır. Bu bağlamda her ne kadar teoriden pratiğe yansıması her dönemde istenildiği gibi gerçekleșmemiş olsa da İslâm eğitim anlayışının hâlâ Müslümanların ve insanlığın sorunlarına çözüm üretebilecek teorik gücünü kaybetmemesi, onun dogmatik yönü ağır basan bir pedagojiye sahip olmadığı iddiasını desteklemektedir.

Kuşkusuz ki Kur'an'ın hakikati farklı doğru parçaları olarak barındırması ve bunun için tefsire ihtiyaç duyulması kabülünde olduğu gibi farklı kıraatlerin kabülü de Müslümanlar açısından sorun olarak görülecek bir ihtilaf sayılmamıștır. En temel ve en kutsal metnin okunuşuyla ilgili bu tutum İslâm eğitiminin epistemolojik yaklaşımını olumlu etkilemiştir. Nitekim klasik İslâm eğitimcileri arasında sayılan Kâbisi'ye göre Kur'an'ın yedi kıraat üzerine okunması öğretmen ve öğrencilerin kafasını karıştıracak bir durum değildir. Bu okuyuşlardan birini tercih etmenin diğerlerini inkâr anlamına gelmediğini açıklayan Kâbisi sahih kıraatlerin biri diğerini tefsir eden veya manaları birbirine muhalif olup biri nasih, diğeri mensuh olan ayetler gibi (Kâbisi, 1996, 87) görülmesini istemektedir.

İslâm eğitiminin kendine özgü bilgi anlayıșının uygulamaya yansımaları İslâmiyet'in doğuşundan itibaren Müslüman toplumların karşılaştığı kültürlerle girdiği ilişkilerde de ortaya çıkmaktadır. Esasen İslâm, ilk zuhur ettiği günden beri çok kültürlü bir yapı içeresinde gelişmiştir. Nitekim ilk Müslüman toplumu, en soylular ile önemli bir kısmı köle olan en zayıflardan oluşmaktadır. Ayrıca bazı Müslümanların birkaç yıl geçmeden Habeşistan'da farklı bir inanç toplumunda yaşamayı tecrübe ettikleri bilinmektedir. İslâm daha zuhurundan çeyrek asır geçmeden birçok farklı kabile, şehir, devlet ve etnik yapıyı bünyesine dâhil etmiş ve bu durum sonraki dönemlerde de devam etmiştir. Müslüman toplumlar tarihin her döneminde güçlü kültürlerle mücadele ve etkileşim halinde olmuştur. İlk dönemlerinde Roma, Sâsânî gibi büyük devletlerle kurulan temas bir anlamda kadim YunanHelen ve Fars kültürü ile kurulan temas olmuştur. Daha sonra ise diğer kadim kültürlerden olan Hint ve Çin kültürü ile temasa geçilmiştir. Müslümanlar bu kültürlerle bir mücadele içine girmiş olsalar da gerçeğin başka inançlar ve kültürler içerisinde de bulunabileceği fikrinde hareketle bu kültürlerde üretilmiş bilgilerden faydalanmasını bilmişlerdir. Abbasiler döneminde yapılan tercüme hareketleri bu durumun en önemli kanıtlarından biridir. Elbette bu durum İslâm düşüncesinde faydalı olan her doğru bilgiye değer verilmesi gerektiği anlayışının hâkim olunması sayesinde gerçekleşebilmiştir.

Lewis'in belirttiği gibi İslâm medeniyeti kadim Ortadoğu, Yunan ve Fars bilgi ve yeteneklerine sahip çıkmakla kalmamış aynı zamanda onlara Çin ve Hint medeniyetinde eklemeler yapmıştır. Derleme ve korumanın ötesine geçen Müslüman bilginler bugünkü bilimin gelişmesine büyük bir katkı daha sunmuşlardır: Kendilerinden öncekilerin pek kullanmadığı deneyi bir yaklaşım olarak geliștirmek. Bu sayede evrensel bilim ve düşünce mirası Batı'ya intikal edebilmiş bugünkü batı 
biliminin ve düşüncesinin oluşması mümkün olmuştur (Lewis, 2020, 11-12; 9396). İslâm medeniyetinin tarihi süreçte diğer medeniyetlerle girdiği ilişkinin niteliği ve yoğunluğu bu medeniyetin katı dogmatik bir eğitim geleneğine sahip olamayacağının önemli bir göstergesidir. Zira katı dogmatik bir anlayıșın kapalı toplum davranışı özelliği göstermeye meyilli olduğu rahatlıkla söylenebilir. Katı dogmatik anlayıș, zorunlu olarak girdiği kültürlerarası ilişkilerde başka kültürlerden alma davranışının taraftarı olmadığı gibi başka kültürlerden etkilenmeme adına aşırı refleksler de gösterebilmektedir. Bunun aksine İslâm medeniyetinin tarihi seyri ise onun temas ettiği kültürlerle karşılıklı yoğun etkileşime girdiği, temel inanç ve ilkeleri muhafaza etmek kaydıyla sürekli bilgi ve kültür alışverişinde bulunduğunu göstermektedir. 0 halde İslâm medeniyetinin ve eğitiminin sahip olduğu dogmaların ve doktrinlerin hiçbir zaman "katı" nitelemesi alacak biçimde kör bir taassubu ifade etmeyeceği söylenebilir².

İslâm eğitim geleneğinin katı dogmatik bir yapıda olmadı̆̆ının göstergeleri, İslâm medeniyeti içerisinde oluşmuş ekolleri ve yorumları birbirinden ayıran sınır çizgileri üzerinde de görülmektedir. Bununla ilgili olarak İslâm medeniyetinde ortaya çıkan fırkaların ve yorumların temelde bir doktrin savunuculuğuna dayanmadığı iddiasının doğruluğu bazı izler üzerinden takip edilebilir. Şöyle ki; ilk olarak, İslâm medeniyetinde ortaya çıkan fırkalaşmanın temel nedenlerinin doktrin kaynaklı olmaktan ziyade metodolojik ya da politik saiklere dayandığı görülmektedir. Fırkaların ortaya çıkmasında doktrin savunmacılığı ancak ikinci ya da daha alt nedenler arasında sayılabilir. Lewis $(2020,117-118)$ de İslâm medeniyeti içerisinde doğru ve sapkın inanç/yol şeklinde bir ayrım yapan manevi lordların (din adamı vb. otorite) ve mekanizmaların olmadığına, farklılığın ana akım ile onun uzağında kalan bireyler üzerinden söz konusu olduğuna dikkat çekmektedir. Buna göre İslâm medeniyetinde en derin bölünme olarak görülen Sünni-Şii ayrımı dahi temelde bir doktrin meselesine değil, siyasi açıdan liderin kim olacağı tartışmasına dayanmaktadir.

İkinci olarak ise firka, mezhep mensubiyetinin din mensubiyeti gibi algılanmadığının, bu yanılgıya düşen bazı istisnalar dışında, göz ardı edilmemesi gerekmektedir. Mu'tezilî görüşleri terk eden Ebu'l Hasan el-Eş'arî ve Hasan el-Basri'den ayrılıp Mu'tezileyi kuran Vâsıl b. Atâ örneğinde olduğu gibi, bilginlerin mensup olduğu ekolden farklı bir ekole geçebildiği ${ }^{3}$ ya da tasavvuf ilmini adeta yeniden keşfettiğini ilan eden Gazzâlî örneğindeki gibi bakış açısında köklü değișimler yaşayabildiği görülmektedir. Aynı zamanda ekollerin de kendi içerisinde geniş spektrum göstermekte olduğu, Şia'nın diğer kollarının aksine Raşid Halifeleri kabul eden Zeydîler örneğinde olduğu gibi çoğunlukla homojen bir ekol yapısından söz etmenin mümkün olmadığı görülmektedir. Bu anlamda ehl-i hadis ve ehl-i rey ayrımının

2 İslâm eğitiminin dogmatik ve doktriner karakteriyle ilgili geniş bilgi için bk. Meydan (2016)’ın "Doktriner Düşünce ve Din Eğitimi: Anlamlı Öğrenme ve Bireysel Manevi Tecrübe Bağlamında Bir Değerlendirme" adlı çalışmasına bakılabilir.

3 Yakın zamanlarda dâhi Sünnilik ve Şiilik arasında geçiş yapan tanınmış bilginlere rastlanılmaktadır. Bu konuyla ilgili Üzüm (1997)'ün "Sünnilikten Şiiliğe, Şiilikten Sünniliğe Geçen İki Müellif ve Eserleri" adlı çalışmasına bakılabilir. 
da büyük oranda metodolojik zorunluluklardan kaynaklanan çok genel bir ayrım olduğu söylenebilir. Zira bir alanda rey taraftarı olan biri diğer bir alanda nakli esas alabilmekte ya da tam tersi bir durum söz konusu olabilmektedir. Câbirî (2001, 115-116), bu konuda rey ehli olan Ebû Hanîfe'nin itikatta akılcı Mu'tezile karşıtı olmasını, Mu'tezilî olan Nazzâm'ın da fikıhta rey ve kıyası kabul etmemesini örnek gösterir. Bunun yanında Ehl-i hadis içerisinde zikredilen bilginlerin birçok konuda aynı düşünmedikleri görülmektedir. Aynı durum ehl-i rey için de geçerlidir. Nitekim Hanefî mezhebi ismini kurucusu Ebû Hanîfe'den almıș olsa da mezhebin resmi görüşü haline gelen çoğu görüş onun görüşlerinden farklı muhâlif görüşlere sahip olan öğrencilerinindir. Ayrıca çeşitli durumlarda bir mezhep mensubunun farklı bir mezhebi taklîd etme serbestliği bulunmaktadır. Mezhepler arasında keyfi dolaşım müzebzib olmaya (bocalamaya) neden olacağı için doğru bulunmamakla birlikte zorlayıcı sebeplerde farklı görüşlerin tercih edilmesinde bir sorun görülmemiştir. Bu konuda en dikkat çekici noktalardan biri de kendi mezhebine göre abdest almayan veya abdesti bozulmuş sayılan farklı bir mezhebi benimsemiş kimselerin arkasında namaz kılınmasında bir sorun görülmemiş olunmasıdır. Bizzat mezhep imamları birbiri arkasında namaz kılmış, başka bir mezhebin doğrusuna göre ibadet yapmayı caiz görmüşlerdir. Kuşkusuz bu durum İslâm eğitim geleneğinin katı dogmatik bir anlayıșa sahip olmadığının önemli bir göstergesidir. Bütün bunlar dikkate alındığında İslam kültüründe çok görüşlülüğün ve görüşler arasında tercih değișikliklerinin sorun olarak görülmemesi Bardakoğlu (2017, 25)'nun ifadesiyle; İslamın evrenselliğini sağlayan "bilinçli boşluk alanı”nın farkında olma durumu olarak ifade edilebilir.

İslâm medeniyetindeki mezheplerin mensuplarını katı sınırlara hapsetmeyen yapısının Hristiyanlık gibi dinlerde görülmediğine dikkat çeken Makdisi (2012, 33), bu sebepten dolayı İslâm hukuku için "sect" (mezhep, firka) ya da "rite" (dinî tören, ayin farklılığına dayanan alt birim) yerine "school" (ekol) teriminin kullanılmasının daha doğru bir tercih olarak kabul etmektedir. Makdisi'ye göre bu konuda Schacht'in "kadim hukuk ekollerinin ekol içinde katı doktrin birliğini, formel bir öğretimi ve resmî statüyü ifade etmediği tespiti" oldukça yerinde bir tespittir (Makdisi, 2012, 34). Makdisi'nin İslâm medeniyetinde hukuki açıdan ayrılıkların mezhep olarak sınıflandırılamayacağı ancak ekol olarak tanımlanabileceği görüşü, İslâm medeniyetinin dogmatik bir eğitim anlayıșına dayanamayacağına da işaret etmektedir. Zira mezhep ve firka gibi kavramlar ekol kavramına kıyasla daha fazla katı dogmatikliği çağrıștırmaktadır. Bu doğrultuda Müslümanlar arasında fıkhi mezhep tercihini abartılı bir biçimde önemseyenler din ile ilgili bilgisi yetersiz olan kişiler olarak görülmüş ve bu kişilerin durumu mizahi anlatılara konu olmuştur. Benzer biçimde tasavvufi ekoller de keskin çizgilerle birbirinden ayrılmamıştır. Aynı kişinin birden fazla tarikatın icazetine sahip olması ve aynı kişinin farklı tarikatların şeyhi konumunda olması mümkün olmuştur.

\section{2. İhtisaslaşma, Akademik Özgürlük ve İlmî Saygınlık Meseleleri Açısın- dan}

İslâm eğitim geleneğinde "ihtisaslaşma" kavramının bugünkü modern eğitimdeki ihtisaslaşmadan daha verimli bir boyutu olduğunu vurgulayan Hallaq 
(2020, 128), Müslüman bilginlerin/entelektüellerin disiplinler arası eğitiminin ve uzmanlığının "disiplinler öncesi” eğitime dayandığına dikkat çekmektedir. Dolayısıyla çağdaş eğitimde genel eğitimin ardından uzmanlık eğitimi ve onun da ardından disiplinler arası uzmanlık şeklinde bir sıralama takip edilirken Müslüman bir entelektüel henüz bir uzmanlaşma alanı tercih etmeden önce yoğun ve ciddi bir disiplinler arası eğitim almaktadır. Bu yüzden çağdaş eğitimde ihtisaslaşma disiplinleri ayrıştırma eğiliminde iken İslâm eğitiminde ihtisaslaşma disiplinleri yakınlaştırma eğilimindedir. Çağdaş bir bilim insanı çalıştığı konu kendi alanı dışında bir bașka alanla çakıştığında diğer alana bilimsel olarak dâhil olabilirken, İslâm eğitim geleneğinde bilim insanları en çok çalıșma yaptığı alanların dışında da doğa bilimleri ilahiyat, İslâmi ilimler, hukuk, edebiyat dil bilimleri, matematik gibi alanlarda genelde uzmandır (Hallaq, 2020, 128-129). İslâm eğitiminin bu yaklaşımı sayesinde Müslüman araştırmacılar farklı alanlardaki bilgilerin izini sürmeye hem yetkin hem de istekli olmuştur. Tek bir disiplin içerisinde kabul görmüş bilgiler yerine farklı disiplinlerin ürettiği bilgileri birlikte kullanmaya yönelmişlerdir. Problemleri farklı yöntemlerle ele alabilmeyi sağlayan bu durumun onların farklı doğruların ve farklı çözümlerin varlığına olan aşinalığını arttırdığı söylenebilir. Ayrıca ihtisaslaşmanın bu şekilde anlaşılması, Müslümanların bilgi üretimi ve paylaşımı davranışlarına ahlaki bir olgunluk kazandırmış, güçlü bir etik duruş göstermelerini kolaylaştırmıştır.

İslâm eğitim geleneğinde başarılı bir eğitim sürecinin sonunda verilen uzmanlaşma belgeleri (icazetnâmeler), hem son aşama değerlendirmelerin yapılış biçimi bakımından hem de icazet alanının sahip olduğu yeterliliklerle ilgili açıklamaları içermesi bakımından İslâm eğitiminin sadece bilginin aktarımına dayanan bir eğitim olmadığını göstermektedir. Bahsi geçen icazetnâmelerin bir kısmında icazet belgesinin çeşitli münâzaralar sonrasında verildiği, icazeti alan kişinin akıl yürütme ve muhakeme yapma gibi zihni becerilerinin olgunlaşmış olduğu, zor ve anlaşılması güç meselelerle iştigal edebilecek düzeyde olduğu bizzat belirtilmiştir (bk. Stewart, 2019, 51). Görüldüğü üzere icazetname hak edişinde yeni bilgi üretme kapasitesinin önemli bir kriter olarak değerlendirildiği görülmektedir. Söz konusu yetkinlik belgeleri, bilhassa hukuk alanında, belge sahibinin özgür görüş bildirmesinin önünü açan, akademik özgürlüğü garanti eden yetkilendirme belgeleri haline dönüșmüştür. Böylece İslâm eğitim geleneğinde yeni bilgi üretiminin önünde engel olabilecek otoriteler başka bir otorite (icazetnâme) tarafindan engellenmiş olmaktadır.

Bunun yanı sıra bahsi geçen icazet belgelerinde müphem konulardan ve bilinmesi zor görünen konulardan çekinmemenin, bu konularla baş edebilme arzusuna sahip olabilmenin bir yetkinlik olarak zikredildiği görülmektedir. Bu durum İslâm eğitim anlayışının bilginin otoriteden aktarımından ibaret olmadığına, her alanda ve konuda yeni bilgi üretebilme amacına uygun eğitimsel hedeflere sahip olduğuna işaret etmektedir. Benzer sebeplerden dolayı Makdisi $(2012,292)$ de fetva verme yetkisine sahip müftînin fetva verme faaliyetini, İslâm eğitim geleneğinde akademik özgürlügün en açık biçimi olarak görmektedir. Zira bir müftînin fetva verirken başka müftîlerin fetvalarını taklîd etmekten kaçınması, kendi mezhebi de dâhil olmak tüm dış etkilerden bağımsız bir şekilde kişisel takdir yetkisini 
kullanabilmesi son derece önem arz etmektedir. Bu bağlamda İslâm eğitim geleneğinde akademik özgürlüğün hem görüşlerin çekinmeden ifade edilebilmesini hem de bilgi üretme ve edinme sürecinde özgün olmayı ifade ettiği söylenebilir.

Makdisi (2007, 327-330), İslâm eğitimi geleneğinde akademik özgürlüğü "icma, icazet, ictihad ve taklîd" mekanizmalarıyla ilişkili olarak ele almıştır. Ona göre icma, sahih dini belirleyecek meclisin hazır bulunamayışından doğmuştur. Münâzara etkinliği ve icazet belgeleri ise icmaya ulaşmanın gereği olarak ortaya çıkmıştır. Bugünkü doktora tez savunmasına benzeyen tartışma metoduna dayalı bir sınav şeklindeki uygulamayla (münâzara) alınan icâzet belgesi akademik özgürlüğün de yetki belgesi anlamına gelmekteydi. Zira Makdisi (2007, 328)'nin ifadesiyle İslâm eğitim geleneğinde akademik özgürlük "bir tezin lehinde ve aleyhinde tüm görüşleri sistematik olarak inceleyen bir araştırma metodu aracılığıyla yapılan bir hakikat arayıșıdır”. Bu anlamda hem öğrenme özgürlüğü, hem de öğretme özgürlüğü vardı. Bu özgürlükler taklîd ve ictihâd kavramlarıyla karşılanmaktadır. Avamın bilgi elde etme yolunu ifade eden "taklîd", ictihâd mekanizmasını tetikleyen dolayısıyla akademik özgürlüğü ortaya çıkaran bir mefhumdur. Müsteftî (fetva talep eden) müftînin (fetva veren) fetvasını kabul etme hususunda bir zorunluluk içerisinde değildir. Müsteftî bir konuda birden fazla müftîye başvurabilir ve bu fetvalardan birini tercih edebilir. Zira kadının görüşü kaza ve hüküm yani hukuki karar değildir. Müsteftî için kesin bilgiyi ifade etmez ve müsteftî isterse başka fetva verecek müftiye başvurmada serbesttir. Birden fazla hekime görünmek isteyen hasta gibi birden fazla müftiye danışabilir. Makdisi'nin bu anlatısına göre İslâm hukukunda taklîd avam açısından olumsuz anlamından ziyade yetki ile donatma anlamında kullanılmaktadır. Bir anlama avamın bilgi tercih etme hakkını da ifade eden taklîd, bilgilenim sürecinde kesin bilgi dayatmasını kabul etmemektedir. Çăg rışım yaptığı olumsuz anlamın ötesinde temelinde tercih özgürlüğü olan taklîd, fakihin akademik özgürlügünün ortaya çıkmasını da sağlamaktadır. Dolayısıyla hem fakih için hem de avam için farklı görüşleri benimseme ve kendi görüşünü özgürce şekillendirebilme söz konusudur. "Taklîd", fakih için kullanıldığında ise olumsuz anlama dönüşmekte, "kör taklîd" veya "kölece taklîd" tanımlamaları söz konusu olmaktadır. Çünkü görüş geliştirmeyen fakih bilgi üretme sorumluluğundan kaçmış ve misyonundan uzaklaşmış olmaktadır.

Bugün olumsuz bazı çağrışımlara ve değerlendirmelere neden olmakla birlikte farklı açlardan ele alınması gereken bir diğer konu da İslâm eğitim geleneğinin skolastik karakteridir. İslâm eğitim geleneğindeki hakikati ortaya çıkarma yani sahih dine ulaşılabilme amacına dayanan skolastik metot, İslâm medeniyetinde bilginin ve bilimin özgürlügünü garanti altına alan bir metottur. Görüş ayrılıklarının varlığına dayanan skolastik metod görüşlerin sürekli olarak tenkide ve eleştiriye maruz kalabilmesinin korunabildiği bir dengeyi gerektirir. İslâm eğitim geleneğinde kendisine veya başkasına ait olup olmamasına bakılmadan doğruluğuna ya da yanlışlığına kanaat getirilen bir görüşün beyan edilmesi vicdani bir sorumluluk olarak kabul edilmektedir. Görüş ayrılıkları sadece izin verilen veya teşvik edilen bir durumu ifade etmemektedir. Aynı zamanda “emr-i bil ma'rûf nehyi ani'lmünker" ilkesi gereği vicdani bir sorumluluğu ifade etmektedir (bk. Makdisi, 2007, 330-332). 
İslâm eğitimi uygulamalarında akademik tartışmaların büyük bir önemi olduğu görülmektedir. Başta hukuk alanı olmak üzere kelâm, felsefe, tasavvuf, dil vb. alanlarda münâzara önemli bir öğretim uygulaması olmuştur. İslâm eğitim geleneğinde herhangi bir konuda bilimsel tartışma; karşılıklı mektup, risale, reddiye vb. yazılı materyal kullanmak suretiyle de yapılabilmekteydi. Ancak fiziki bir ortamda aynı anda hazır bulanmak şeklinde yapılan münâzara geleneği, İslâm eğitim geleneğinde daha yaygın bir uygulama olarak ortaya çıkmaktadır. Makdisi $(2007,210$ 211; a.mlf., 2012, 46-47)'nin işaret ettiği gibi; başlangıçta bir bilginin namaz sonrası verdiği dersi, makamı ve derse katılanları ifade eden meclis kavramı daha sonra ilmi tartışmaların yapıldığı, bilginlerin görüş alışverişinde bulunduğu her türlü oturum için kullanılmaya başlanmıştır. Bu meclisler (meclisü'l-ilm, mecelisü'nnazar) dinî ilimlerin dışında tıp ve edebiyat gibi alanlardaki tartışmalar içinde düzenlenirdi. Dâru'l kütüb'lerde de yapılabilen bu tartışma meclisine katılım için herhangi bir ön şart ve kayıt söz konusu olmamakta, görüşünü savunmak ya da karşı görüşü çürütmek isteyen her uzman rahatlıkla katılabilmekteydi.

Âmîdî’ nin el-İhkâm adlı eserini inceleyen Weiss (2019, 127-129)'in tespit ettiği bazı ifadeler, İslâm eğitim geleneğinde bilginin salt aktarımının ötesinde bir öğretim yapıldığına işaret eden, oldukça iyi bir biçimde sistemleşmiş, bir münâzara ve muâraza (karşı delil getirme) kültürünü tanıtmaktadır. Söz konusu ifadelerden bazıları: "Bunun ispatlayıcı değerini teslim ediyoruz, ancak ona şu delil muâraza etmektedir", "söylediğini sorguluyorum", "bu sorgulanabilir bir şeydir" gibi ifadelerdir. Bu ifadeler bir konuda çatışan farklı fikirlerin toptan reddine ya da kabulüne dayanmayan, karşıt görüşlerdeki kısmî doğrunun varlığını kolayca kabullenen bir bilimsel tartışma kültürüne işaret etmektedir. Nitekim bilginin hocadan dinleme, ezberleme ve tekrar üzere bina edilmesi gerektiğinin vurgulayan Zernûci dâhi; içerisinde hem tekrarı barındıran hem de bilinenden fazla bilgiyi ortaya çıkaran bir etkinlik olarak gördüğü için bir konuda münâzara etmeyi o konu üzerine bir ay boyunca ders tekrarı yapmaktan daha faydalı görmektedir (Zernûci, 1989, 107).

İslâm eğitim geleneğinde münâzara sürecinde ve sonucunda büyük çoğunluğun görüşüne karşı koyan grup çok küçük dahi olsa göz ardı edilmemiştir. Herhangi bir konuda kabul edilen görüş zikredildikten hemen sonra hilâfen sözcüğü eklenmek suretiyle muhalif görüşlere de yer verilmiştir. Münâzara meclislerinde kişinin görüşlerini özgürce ifade edebilmesine dayanan "ilmi saygınlık", yerleşik olan bilgiye ve bilgi otoritesine duyulan saygıdan daha büyük olduğu için münâzaranın sonuçları her zaman için ön görülemez olmuştur (Weiss, 2019, 127 131). Münâzaralar sonucunda her an yerleşik olan bir bilginin yeni üretilen bilgi karşısında hezimete uğraması ya da alanında otorite kabul edilen bir âlimin bir çömezin ya da öğrencisinin fikirlerini kabul etmek zorunda kalması mümkün olmaktadır.

Bugünkü terminolojide akademik özgürlük olarak ifade edilebilen kavramla ilişki olan "ilmi saygınlık (akademik saygınlık)" İslâm eğitim geleneğinin siyasal, finansal vb. harici otorite güdümünde oluşmadığını gösterdiği gibi İslâm eğitim anlayışının katı dogmatik olmayan karakterini de yansıtmaktadır. Şöyle ki, İslâm eğitim anlayışının dikkat çekici özelliklerinden biri, bu eğitimin büyük oranda öğretmen-öğrenci ilişkisi üzerine kurulmuş olmasıdır. Bilhassa hoca unsuru eğitim 
sürecinde derslerden, programlardan, okullardan daha fazla ön planda tutulmuştur. İslâm eğitim geleneğinde öğrencinin eğitim gördüğü medresenin hangisi olduğundan ziyade hangi hocalardan eğitim gördüğü önemsenmiștir. Öğrenci kavramı, medresenin öğrencisini değil de hocanın öğrencisini ifade etmiştir. $\mathrm{Bu}$ yüzden Zernûci (1989, 60-62), tahsil hayatına başlamadan önce ciddi bir araştırma ve fikir alışverişinde bulunarak hoca seçimini ilk işler arasında saymakta ve hoca seçmeden önce iki ay bir süre öğrencinin hocasını deneme sürecine tabi tutmasını istemektedir. Öğrencilerin münferit olarak hoca arayıșında oldukları, tanınmıș bir medresede eğitim görmek yerine tanınmış bir hocadan eğitim görmeyi önceledikleri görülmüştür. Bazı öğrencilerin burslarından (yevmiyelerinden) feragat ederek başka hocaların ders halkalarına katılmayı tercih ettikleri tespit edilmiştir (bk. Chamberlain, 2014, 100-102; Berkey, 2015, 33-35). Nitekim Dodge (1962, 13), ortaçağda yüzlerce sınıfta farklı farklı derslerin yapıldığı Kahire'yi örnek göstererek, öğrencilerin dersleri, öğretmenleri, sınıfı (ders halkasını) ve ders saatini özgürce seçtiklerinden, herhangi bir zorlamanın söz konusu olmadığı bir eğitim sisteminden bahsetmektedir.

Öğretmenlerin eğitim kurumlarının itibarını bile gölgede bırakan itibarının kaynağı "ilmi saygınlık/bilgiye saygı" olduğu gibi bu saygınlık ilkesi aynı zamanda öğrencilere öğretmenlerini çekinmeden eleştirme, onları korkusuzca objektif bir biçimde değerlendirme imkânı sağlıyordu. Öğrenciler hocalarını yetersizlikleri sebebiyle eleștirebiliyor, medrese dıșında hoca arayabiliyordu. Bunun yanında mümkün olduğunca fazla hocayla mülâki olma, ders aldığı ya da birlikte çalıştığı hoca sayısının fazla olması bir ayrıcalık olarak görüldüğü için öğrenciler olabildiğince çok hocayla çalışmaya gayret göstermekteydi. Medreselerdeki öğrenim hayatında bunu gerçekleştirebilmek için herhangi bir prosedürel engel bulunmamaktaydı. Medrese içinde veya dışında ulaşabildikleri bir ders halkasına dâhil olmaları yeterli olmaktaydı (Chamberlain, 2014, 105-110). Bu sayede doğal olarak bilgi edinme sürecinde tek bir hocanın epistemik otoritesinin öğrenciler üzerinde hâkim olması söz konusu olamıyordu. Her ne kadar İslâm eğitim geleneği öğretici etrafında oluşan bir öğretimi esas almışsa da öğretmenin bilgisine ve karakterine duyulan saygı onları mutlak bilgi otoritesi yapmamıștır. Her zaman bilgileri ve uygulamaları öğrencilerin eleștirilerinden payına düșeni almıștır. Bu konuyla ilgili Makdisi (2012,199-200)'nin “bazı hocaların başarılı öğrencileri kendilerine muhalif olmamaları ve eleștirmemeleri için ücretli yardımcı (muîd) olarak yanında tutmaya çalıștığı" iddiası bulunmaktadır. Bu iddia sağlam kanıtlara dayanmayan abartılı bir iddia olmakla birlikte öğrencilerin hocalarını çekinmeden eleştirebildikleri bir ortamın mevcut olduğuna ve öğretmenlerinde bunun farkında olduğuna işaret etmesi bakımından önemlidir.

\section{3. Öğretmen Merkezlilik ve Ezbercilik Meseleleri Açısından}

İslâm eğitim geleneğinde öğretmenin epistemolojik bir otorite olarak kesin bilginin kaynağı olarak görülmesi meselesi iyi analiz edilmesi gereken bir husustur. Zira ilk bakışta İslâm eğitim geleneğinin bütünüyle öğretmen merkezli bir öğretim anlayışına ve öğretmenin kesin bilgi kaynağı olması inancına dayalı olduğu görülmektedir. Ancak detaylı incelemeler İslâm eğitim geleneğinin öğretmenin bir 
bilgi otoritesi olarak kesin bilginin kaynağı olması konusunda farklı anlayışları birlikte yansıttığı görülmektedir. Bu hususta İslâm eğitimcilerinin eserlerinden basit birkaç örnek verilecek olunursa: Zernûci (1989)'nin “Tâ'lim'ul Müteallim” adlı eseri incelendiğinde hem öğretmenin epistemolojik otoritesini ve aktarılan bilginin ezberlenmesini önceleyen hem de öğrenenin epistemolojik otoritesini ve doğru bilgi ile ilgili farklı kabullerin karşılaştırılmasını (münâzara) önemseyen bir yaklaşımın tercih edildiğine rastlanılmaktadır. Zernûci $(1989,109)$, öğretmenine tam bir teslimiyet göstermesi gerektiğini belirttiği öğrencilere aynı zamanda öğrenciliğin en önemli vasıflarından birinin soru sormak olduğunu bu yüzden öğrenci sözcüğünün yerine kullanılan diğer sözcüğün "mâtekûlü (ne dersin)" olduğunu hatırlatmaktadır. Ayrıca bahsi geçen eserde bilgi arayışında "her zamanda ve her durumda her şahıstan faydalanmak" temeli, bir öğrenme ilkesi olarak ele alınmıştır (Zernûci, 1989, 109). İbn Cemâa (1998) da mezhep imamlarından örnekler vererek "öğretmen (âlim), bilmediklerini kendinden makamca, soyca ve yaşça daha aşağıda olan kimselerden öğrenmekten çekinmemeli” diyerek benzer düşünceler ifade etmiştir. Bu durum, İslâm eğitim geleneğinin öğretmenin kesin bilgi kaynağ olarak görülmesi konusundaki yaklaşımının ne tamamen öğrenci merkezli ne de tamamen öğretmen merkezli epistemolojik anlayış olarak değerlendirilemeyeceğini göstermektedir.

İslâm eğitim geleneğinde Hz. Ali'ye atfedilen, "Bana bir harf öğretenin kırk yll kölesi olurum" ifadesi öğretmenliğin toplum içerisinde üstlendiği işlevin öneminin altını çizdiği kadar öğrencinin hocasıyla ilişkisinde sadakat kavramının da altını çizmektedir. Bu bağlamda hem Zernûcî hem de İbn Cemâa öğrencinin öğretmenine karşı itaatkâr olması gerektiğini ifade etmiştir. Öğrencinin hocalarına şeyhmürit, baba-oğul ilişkisi benzeri bir ilişki ile bağlı olması, öğrencinin her açıdan hocasını örnek alması gerektiği dile getirilmiştir (bk. Zernûci, 1989). Ancak öğrenci ile hocası arasında bu bağ öğretmenin aktardığı bilginin eleştiri süzgecinden geçirilmesi gerektiği gerçeğini örtememiş, öğrenciler tarafından hocalarının görüşlerine aykırı olan yeni bilgilerin üretilmesine engel olamamıştır. İmam Ebu Yûsuf, İmam Muhammed, İmam Züfer gibi bilginlerin birçok konuda hocaları Ebu Hanîfe'den farklı görüş ortaya koymaları bu durumla ilgili güzel bir örnektir. İslâm eğitim geleneğinde öğretmen ile öğrencisi arasında kurulması gerekli görülen muhabbet bağında öğretmenin konumunun yüceltilmesi daha çok öğrenme faaliyetinin diğer insani faaliyetler karşısında yüceltilmesinin bir tezahürü olarak görülmelidir. Öğreticinin bu şekilde müstesna bir yere konulması, onun aktardığı bilginin her zaman tartışmasız bir biçimde müstesna bir yere konulması anlamına gelmemektedir.

İbn Cemâa, "öğrencinin hekim karşısındaki hasta” misali hocasına teslim olmasını, hocasının karşısında kendi görüşünü bir kenara bırakmasını ögüutlemiştir. Ancak bu "koşulsuz itaat öğüdü" İslâm eğitim geleneğinin genel görüşünü ve uygulamasını yansıtmamaktadır. Yukarıda da bahsi geçtiği üzere öğrenciler öğretmenler arasında fayda prensibiyle hareket etmekte ve tercih yapabilmekte, öğretmenleriyle ilgili kişisel değerlendirmeleri sonucunda öğretmenlerini değiştirebilmekteydi. Nitekim İbn Cemâa'nın öğrencinin öğretmenine "niçin?-neden?", "kabul etmiyorum, itiraz ediyorum" gibi sözler dememesini öğ̈̈tlemesinin öğrencileri 
aktarılan bilgileri sorgulamaktan men etme açıklaması taşımadığı yine onun açıklamalarının devamında görülmektedir. İbn Cemâa'nın öğütlerinin öğretmeni mutlak bilgi otoritesi olarak göstermekten ziyade öğretmen öğrenci ilişkisinde ve ikisi arasındaki iletişim üslubunda öğretmene saygıyı ön plana çıkaran öğütler olduğu görülmektedir. Peygamberler gibi ismet sıfatına sahip olmadığı için öğretmenlerin görüşlerinde hata yapabileceğini, yanlış kanıtlar kullanabileceğini hatırlatması ve öğrencilere çekinmeden soru sormalarını öğütlemesi; öğrencilerin görüşlere nasıl itiraz edeceklerini açıklaması, İbn Cemâa'nın öğrencileri eleștirmekten ve sorgulamaktan uzak tutmayı amaçlamadığının kanıtları arasında sayılabilir (İbn Cemâa, 1998, 106-107, 120-121).

İslâm eğitim geleneğinde "ezbercilik" ve "öğretmen merkezlilik" kavramlarının kitap üretimi ve kitap sahibi olabilme imkânıyla ilişkili olan yönleri vardır. İslam medeniyetinde kitaplar eğitimde vazgeçilmez kaynaklar görülmekte ve kitap yazmaya, kitap sahibi olmaya özel bir önem atfedilmektedir. Bununla birlikte bir öğrenci için bilgiyi kitaptan doğrudan elde etmek doğru bir uygulama olarak kabul edilmemiştir. Yaygın görüșe ve uygulamaya göre öğrenme, metnin bir hoca nezaretinde hocaya sesli olarak okunması suretiyle (karae ala) ya da bir hocadan, bir müelliften bir metnin işitilmesi suretiyle (semi'a min) gerçekleștirilmekteydi (Berkey, 2015, 36). Öğrencinin bilgiye kendi bașına ulaşmasını engelleyen bu uygulamalar öğrencinin bilgiyi değerlendirmesini ve bireysel olarak yapılandırmasını engelleyen problemli bir durum olarak görülmektedir. Bu durum İslâm eğitiminin öğretmen merkezli ve kontrollü bilgi aktarımı șeklinde yapıldığı intibaını uyandırmaktadır. Ancak matbu eserlerin dolaşımda olmadığı o dönemlerde el yazısıyla üretilen metinlerin her zaman okunaklı yazılmadığı, birçok kez okunamadığı ve yanlış okunabileceği riski göze alındığında bu uygulamanın bir tedbir uygulaması olduğu söylenebilir.

El yazmalarından kaynaklı problemlerin yanı sıra Berkey $(2015,40)$ 'in dikkat çektiği gibi Arapça sesli harflerin yazılmamasından kaynaklı yanlış okumaanlama problemi de bulunmaktaydı. Bunun yanında bir hocanın veya bir müellifin metni okuması esnasında dinleyici olan çok sayıda kişiye metnin ulaştırılma imkânına kavuştuğu, ancak metnin yazılı olarak bu kadar kişiye ulaştıracak imkânların henüz var olmadığı gerçeği de dikkate alınmalıdır. Bu durumda bu tür uygulamalar İslâm eğitiminin sadece öğretmen merkezinde yapılan ve bilgi aktarımına dayalı bir eğitimden ibaret olduğunu göstermemektedir. Zira bu tür uygulamalar metindeki bilgilerin eleştiriye tabi tutulmasına engel olmamıştır. Çoğu kez halka açık ders halkalarında metnin sözlü olarak telif edilmesinden hemen sonra metnin içeriği tartışılmaya başlanmıştır. Medreselerde bilginin edinilmesi hoca nezaretinde sesli okumalara dayansa da bilgilerin karșılaștırılma uygulaması olan münâzara ve muâraza da bir diğer öğretim etkinliği olarak devamını sürdürmüştür.

Kitapların geleneksel usullerle çoğaltılmasından dolayı kitap sayısının azlığı, kitaba ulaşma imkânlarının kısıtlı olması ve eğitim-öğretim için yapılan seyahatlerde kitapların nakledilmesinin güçlük oluşturması gibi nedenler İslâm eğitim geleneğinde ezberleme etkinliğinin ön planda olmasını zaruri kılmıştır. Eğitimin ezberleme yeteneği ve etkinliği üzerine kurulması, İslâm eğitiminin ezberci bir eğitim olarak görülmesine sebep olmaktadır. Ezberci eğitim nitelemesi çağdaş eği- 
tim açısından; doktriner, ideolojik, tek tipleştirici (stereotipik) vb. eğitim anlayışlarını ve otoriteden bilgi aktarımına dayalı bir öğretimi çağrıştırmaktadır. Ancak çağdaş eğitim anlayışının ezberleme etkinliğine biçtiği değer ile İslâm eğitim geleneğindeki uygulamalar birbirinden farklı olarak ele alınmalıdır. Kuşkusuz İslâm eğitiminde ezberleme yeteneği ve ezbercilik tartışma götürmez bir biçimde hâkim bir yer kaplamıștır. Öyle ki ezberleme yeteneği yüksek olan kişiler daima övgüyle anlatılmış, metinleri ezbere okumak yerine kitaplardan okuyanlar ayıplanmış, öğrencilerin hafıza gücünü arttırmak öğretimin hedefleri arasında olmuş ve buna göre beslenme tarzı benimsenmiştir. Nitekim İslâm eğitim tarihinde ezberlediği kitabın isminin kendisine lakap olduğu, ezberleme gücü sayesinde hatırı sayılır miktarlarda ödül alan birçok isme rastlamak mümkündür (bk. Berkey, 2015, 41 43; Chamberlain, 2014, 175-176). Hafıza gücünün zayıf olması büyük bir eksiklik olarak görüldüğü için eğitimciler sıklıkla öğrencilerin hafızasını zinde tutacak bazı beslenme ve egzersiz önerilerinde bulunmuştur (bk. Zernûci, 1989, 97-98; 151; İbn Cemâa, 1998, 94-95).

İslâm eğitim geleneğinde ezberciliği ön plana çlkaran bütün bu durumlara rağmen bu geleneğin öğretim anlayıșında öğrenmenin sadece bilgi aktarımından ibaret görüldüğü anlamına gelen bir sonuç çıkartılmamalıdır. Çünkü İslâm eğitim geleneğinde ezberciliği ön plana çıkaran bu yönelim bir tercihten ziyade mevcut teknolojinin sunduğu imkânlarla paralel olarak metinlere ulaşma güçlüğünden kaynaklanan bir zorunluluk sonucunda ortaya çıkmıştır. Bu zorunluluğun adeta ezbercilik yöntemiyle bilgi transferini bir yayım faaliyeti türü haline getirdiği söylenebilir. Şöyle ki, arz-talep ilişkisine dayalı olarak talep edilen kadar yazılı metnin üretilmemesi, eğitim hizmetleri içerisinde ezberlediği metinler sayesinde geçimini temin eden uzmanlar zümresini oluşturmuştur. Yazılı kaynaklara sınırlı erişimin olmasına ve bu kaynaklara sahip olmanın ciddi bir ekonomik külfetinin olmasına o kaynakları korumanın güçlülügü de eklenince hafızada olan bilgi makbul kabul edilmiştir. Nitekim tarih boyunca Müslümanların yazılı kaynaklarının yangın, sel gibi afetlerin yanı sıra istilacı kavimler tarafından da imha edilmesinin tecrübe edildiği durumlar birçok kez ortaya çıkmıştır.

Ezberlemenin bu kadar ön plana çıkarılmasına rağmen bilgilerin yazılı olarak kayda geçirilmesi gerektiği inancı zayıflamamış, kitaplara duyulan sevgi eksilmemiştir. Daha da önemlisi ezberleme eylemi hiçbir zaman anlama eyleminden koparılmamış, ezberleme sadece bilginin nakil şekli olarak görülmemiștir. İslâm eğitim geleneğinde ezberleme yeteneği ne kadar önemsenmiş ise ezberleme yeteneğinin anlama yeteneği ile aynı olamayacağı ezberleme yeteneğinin anlama yeteneğinden bağımsız bir değer ifade edemeyeceği de o kadar vurgulanmıştır. Bu bağlamda İslâm eğitim geleneğindeki ezberleme metodu Makdisi $(2012,169)$ 'nin ifadesiyle "muhakemesiz ve mekanik bir öğrenme metodu anlamına gelmemektedir". İslâmi ilimlerin farklı alanlarından bilginlerin bu konudaki görüşlerini inceleyen Berkey, $(2015,43)$ "rivayetin daima dirayet ile bir bütünlük oluşturması gerektiği" fikrinin Müslüman bilginler arasında tartışmasız bir biçimde hâkim görüş olduğunu belirtmiştir. Bütün bunlar göze alındığında İslâm eğitim geleneği açısından ezberlemeyi öncelemek ile ezberci eğitim anlayışına sahip olmanın aynı anlama gelmediği görülmektedir. Nitekim Salama (1939 akt. Arjmend, 2018, 26), medreseler- 
de eğitimin metnin ezberlenmesiyle nihayetlenmediğini şöyle anlatmaktadır:

“Bu metinler ezbere öğrenilecek ve öğretmen tarafından üç tefsir seviyesi aracılığıyla açıklanacaktı: Şerh; tefsirler veya dipnotlar (hașiyeler) ve nihai yorum (takrir). Öğretmen, sadece teorik alanlarda değil, hukuk üzerine bir derste bile temel metni "Allah müellifi korusun" sözleriyle okumaya başladıktan sonra, metnin kelimesi kelimesine açıklamasına başlardı. Metni açıkladıktan sonra, öğretmen ilk tefsiri, ardından tefsiri ve son olarak da nihai tefsirini okurdu."

Müslüman eğitimciler eğitim etkinliklerinde ezberleme etkinliğinin oldukça önemli bir yer kaplamasının oluşturacağı sorunların farkında olmuştur. Bu yüzden ezberlemenin bilgiyi koruma amacından kaynaklanan zorunlu bir etkinlik olduğunu, onun bilgi edinmenin asıl etkinliği olamayacağını sıkça vurgulamışlardır. Öğrenme sürecinin asıl amacı olan anlamaya ve uygulamaya ulaștıracak asıl etkinliğinin tartışma, karşılaştırma, eleştirme olduğunu hatırlatmışlardır. Eğitim sistemi içerisinde ezberleme etkinliğinin asıl amacından saptıracak biçimde önemsendiği buna karşılık tartışmanın ve eleştirmenin yeterince önemsenmediği durumlarda Müslüman bilginler eğitim sistemiyle ilgili eleştirilerini yapmaktan çekinmemişlerdir. Bahsi geçen eleştiriyi yapan bilginlerden biri olan İbn Haldûn (2004), bir konuda bilgi sahibi olmayı o konuda münâzara yapabilecek seviyede olmak olarak görmekte, ezberciliğin tartışma ve eleştirmeden daha fazla önemsenmesinin eğitimde zaman kaybına ve başarısızlığa neden olduğunu ifade etmektedir. Kendi döneminden örneklemeler yapan İbn Haldûn'a göre Mağrib medreselerinde doğudakilerden daha fazla ezberciliğe önem verilmesi ve müzakerenin daha az önemsenmesi, Mağribli öğrencilerin eleştirme ve sorgulama yeteneklerinin daha az gelişmesine neden olmuştur (İbn Haldûn, 2004, 603-606; 784-787).

$\mathrm{Bu}$ başlık altında ele alınması gereken bir konu da ana kaynaklardaki bilgilerin ezberlenmesi, (Kur'an ve hadis hafızı olma) geleneğinin İslâm eğitiminin bilgilenme kültürü açısından nasıl değerlendirileceği konusudur. Kuşkusuz İslâm eğitiminin ezberci karakterde olup olmadığı tartışmasında bahsi geçen "hafızlık" geleneği de ele alınmalıdır. İslâm eğitim geleneğinde medreselerde bazı metinlerin ezberletilmesi hususunu açıklarken bahsi geçtiği üzere bazı sosyal, kültürel, teknolojik ve ekonomik sebeplerin bu tarz bir ezberleme geleneğini mecbur kıldığı ve canlı tuttuğu görülmüștü. Kur'an ve hadis metinlerinin ezberlenmesinde de aynı zorlayıcı nedenler söz konusu olmakla beraber, bu metinlerin istisna içermeyecek şekilde, harf-harf, kelime-kelime birebir ezberlenmesi biraz daha farklılık arz etmektedir. Bu durum dışardan bakan bir göz için oldukça katı bir ezbercilik geleneğinin varlığına işaret etmektedir. Watt (2017), Arap-İslâm geleneğinde lafzın doğruluğunun şahısların doğruluğundan (otoritesinden) daha büyük önem taşıdığını, bilginin tamamen nakledilmesine yaklaşmanın ancak lafzın korunması suretiyle gerçekleşeceği inancının hâkim olduğunu dile getirmektedir. Ona göre Kur'an'ın ve Hadislerin ezberlenmesine neden olan bu bilgi anlayışı bütün İslâm eğitimini kendi rengine boyayabilmiştir. Bu anlayıșta yegâne bilgi çok az kişinin bilgisidir ve $\mathrm{Hz}$. Muhammed (s.a.v.) de bu kişilerin sonuncusudur. Watt'a göre Arap kabile toplumunun statik karakterinin bir yansıması sonucu yanılmaz bilgi otoritesinden en yüksek hikmeti elde edebilmek ancak "atalarının yolu”nu takip etmektir ki "ataların yolu” İslâmiyet'ten sonra artık “Hz. Peygamber'in sünnet”i olmuştur (Watt, 


\section{7, 173-174).}

Watt'ın eski Arap toplumunda eski Arap bilgi anlayışının uzantısı olarak yanılmaz bilgi kaynağı sayısını asgari seviyede tutma eğilimini Hz. Peygamber dışındaki bilgi otoritelerini eleme davranışının nedeni olarak sunması bazı açlardan sorunlu ve tartışmalı bir iddiadır. Ancak Watt'ın değerlendirmeleri göz önüne alındığında İslâm eğitim geleneğinde "hafızlık" geleneğinin bilgi-otorite ilişkisi kapsamında daraltıcı mı yoksa genişletici bir etkisinin bulunduğu konusunda bazı noktaların açıklanması kolaylaşabilir. Bu durumda hafızlık geleneğinin Kur'an'ın aktarıcısı ve açıklayıcısı olan Hz. Muhammed'in bilgi otoritesi konumunu muhkemleștirdiği açıktır. Ancak bunun yanı sıra metnin dokunulmazlığını tamamen korumak suretiyle Hz. Muhammed dışında farklı görüşlerin ve yorumların otorite olarak kabul edilmesi önlenmiş olmaktadır. Bu sayede metne erişenin metinden bilgi üretebilme imkânı da korunmuş olmaktadır. Dolayısıyla Kur'an ve hadislerin ezberlenmesi bir açıdan ana metnin yorumlardan arı halini korumak Müslüman bir bireyin Hz. Peygamber'in dışındaki beşeri bilgi otoritelerinden bağımsız olarak bilgiyi orijinalinden üretebilmesini kolaylaştırmıştır.

Detaylı tahlillerin yapılmadı̆̆ı araştırmalarda İslâm eğitim geleneğinde öğrencilerin bilginin pasif alıcısı konumunda olduğu öğretmen merkezli bir bilgi anlayışının hâkim olduğu iddia edilse de, İslâm eğitim geleneği açısından bilgilenim sürecinde öğrenenin aktifliği önem arz etmektedir. İslâm eğitim geleneğinde öğretim etkinlikleri, sınıf düzeyi yükseldikçe öğrencilerin öğrenmede daha aktif rollere sahip olması üzerine tasarlanmıştır. Öyle ki sadece derslere katılan "dinleyici öğrenci (müstemi')" ile derslerdeki faaliyetlere bilfiil katılarak özel çalışmalar yapan “aktif öğrenci (müşteğil)”lere farklı miktarlarda yevmiye ödenmekteydi. Müşteğil öğrencilerin maaşları müstemi' öğrencilerden fazla olmuştur. Müfredat dışında özel çalışmalar yapan müşteğil öğrenciler ihtisas öğrencilerinden olabildiği gibi lisans seviyesindeki öğrencilerden de olabilmekteydi. Bütün kademelerdeki öğrencilerin münâzaralara aktif katılması gerektiği sıkça vurgulanmış olsa da bilhassa müşteğil öğrencilerin münâzaralarda yeterince aktif olmaması hem kendi ilerlemeleri hem de onlardan faydalanacak arkadaşlarının ilerlemeleri açısından kabul edilemez görülmüştür (bk. Makdisi, 2012, 260-262; 304-305).

İslâm eğitim geleneğinin bilginin aktarımından ibaret olup olmadığını tartışırken üzerinde durulması gereken önemli hususlardan biri de İslâm eğitimindeki şerh geleneğidir. Medreselerde okutulan kitapların yüzyıllar boyunca aynı eserler olması, bu eserlere yapılan şerhlerle öğretime devam edilmesi, İslâm eğitimi açısından yeni bilgi üretiminde problemler yaşandığına dair bir görüntü çıkarmıştır. Tahmin edileceği üzere şerh geleneği ilk bakışta anlaşılamayanı açıkladığı ve bilinme ihtimali düşük olan bir kültüre/bir alana özgü ifadeleri veya jargonu açıkladığı için bir ihtiyaç gibi görünmesinin yanı sıra gereksiz tekrarlarda boğulma, basit örneklendirmelerin ötesine geçememe, özgün ürünler üretmeye engel olma gibi nedenlerle de eleștirilmiş bir gelenektir. Nitekim Müslüman toplumlarda tercüme dönemi sonrası antik dönemde tercüme edilen eserlerin șerh geleneği ile varlığını sürdürmesi İslâm bilim ve düşünce geleneğinin özgün olmadığı eleştirisine muhatap olmuştur. Oysa İslâm eğitim geleneğindeki şerh geleneği o devrin özgün akademik çalışmalarıydı. Şarihler müstakil bir eser kaleme alırken takip edilen süreç- 
lerdeki gibi metindeki fikirlerinden kendilerine uygun bulduklarını çekinmeden tekrar etmiş, gerekli gördükleri kısımlara muhalefet etmiş ya da ilaveler yapmışlardır. Çünkü orijinal bir eser hazırlanırken de önce problemler/fikirler ele alınır ve bunlarla daha önce ilgilenenlerin çözümlemeleri/görüşleri değerlendirilir. $\mathrm{Bu}$ çözümler ve görüşler içerisinde gerekçeli açıklamalarla bazı fikirler elenir ya da üzerlerine ilaveler yapılır. Bazı durumlarda yeni çözümler ya da metotlar ileri sürülür. Bu durumda, şârihe ait fikirleri ve değerlendirmeleri içeren şerh eserler pekâlâ orijinal eserler gibi görülebilir (bk. İpek, 2017, 126-135). Șerh geleneğinin basit açıklamalarla bilginin aktarımından ibaret görülmediğinin kanıtı olabilecek en güzel örneklerden bir tanesi ise İbn Rüşd (2005)'ün Platon'un Devlet eserine yaptığı şerh çalışmasıdır. Platon'un fikirlerini ciddi bir biçimde değerlendiren bu eser bir şerh çalışmasından ziyade İbn Rüşd'ün görüşlerini içeren yeni bir eser haline gelmiştir.

\section{Sonuç}

İslâm eğitim geleneği açısından bilgi-iktidar ilişkisi, akademik özgürlük, bilimin saygınlığı, tektiplilik, dogmatiklik ve ezbercilik tartışmaları birbiriyle bağlantılı tartışmalardır. Bu gelenekte siyasal veya epistemik otoritelerin eğitim öğretim süreçlerine dolaylı etkilerinden bahsetmek mümkün olsa da bu otoritelerin bilgi üretim sürecine șekillendirici bir etkisinin olduğu görülmemektedir. İslâm eğitim geleneğinde eğitim süreci sonunda yetkinliğin elde edilmesi ve uzmanlığın kullanılması süreci yeni bilgi üretiminin önünde engel olabilecek otorite engelini bertaraf edecek şekilde düzenlenmiştir. Öğretmenlerin müstesna konumlarının yanı sıra öğrencilerin hocalarını çekinmeden eleștirebildikleri bir ortamın mevcut olması, bu geleneğin ne tamamen öğrenci merkezli ne de tamamen öğretmen merkezli olarak değerlendirilemeyeceğini göstermektedir.

İslâm medeniyetinin tarihi süreçte diğer medeniyetlerle girdiği ilişkinin niteliği ve yoğunluğu bu medeniyetin katı dogmatik bir eğitim geleneğine sahip olamayacağının önemli bir göstergesidir. "Akademik özgürlük" ve "ilmi saygınlık (akademik saygınlık)” kavramları etrafında gelișen bilgi/bilgilenme kültürü, İslâm eğitim geleneğinin siyasal, finansal vb. harici otorite güdümünde oluşmadığını gösterdiği gibi İslâm eğitim anlayıșının katı dogmatik olmayan karakterini de yansıtmaktadır.

Bütün inanç sistemleri gibi İslâm'ın da sahip olduğu dogmalar ve doktrinler vardır. Ancak bunlar hiçbir zaman İslâm'ın dogmatik ya da doktriner bir öğretim biçimini seçtiğini göstermemektedir. Kendi inanç ve yargısını üzerinde düşünmeden körü körüne sahiplenmeyi ifade ettiği için bu konuda anahtar sözcüğün "katı" nitelemesi olduğu söylenebilir. İslam eğitim geleneğinde belirli sınırlar içerisinde şüpheciliğe ve çok görüşlülüğe her zaman yer verilmiştir. Bu doğrultuda İslâm eğitim geleneğinin dogmatik ve doktriner yönünün "katı" sözcüğüyle nitelendirilemeyeceği görülmektedir. Atay (1987)'ın da işaret ettiği gibi İslâm'a medeniyet kurma şansı veren şey bizzat bilgiye bu tarz bir yaklaşımın kendisi olmuştur.

İslâm eğitim geleneğinde coğrafyaya, zamana ve diğer şartlara göre farklı müfredatın tercih edilmesinden dolayı öğretim materyallerinin, kaynak metinlerin 
ve ders kitaplarının farklılık gösterdiği, buna bağlı olarak da dolaşımda olan bilgi birikiminin de belli ölçüde farklılık gösterdiği söylenebilir. Eğitim, yapısal ve davranışsal boyutta İslâm dünyasının farklı coğrafyalarında değişme gösterdiği gibi aynı toplum içerisinde de "tektiplilik" nitelemesini bertaraf edecek biçimde değişiklik gösterebilmiştir. Bu durum, İslâm eğitim geleneğinin "tektipleştirici" karekterde olamayacağı konusunda önemli kanıt olarak görülmelidir.

Çağdaş eğitim anlayıșının "ezber" algısından farklı olarak İslâm eğitim geleneğinde ezberleme eylemi hiçbir zaman anlama eyleminden koparılmamış, ezberleme sadece bilginin nakline dayanan mekanik bir öğrenme şekli olarak görülmemiştir. Ezberleme yeteneğinin anlama yeteneğinden bağımsız bir değer ifade edemeyeceği (rivayet-dirayet bütünlüğü) sıkça vurgulanmıştır. Bu durumda İslâm eğitim geleneğinin ezberlemeyi öncelemesinin onun ezberci eğitim anlayışına sahip olduğunu göstermediği söylenebilir.

İslâm eğitiminin bilgi/bilgilenme kültürü, bugünkü eğitim anlayıșımıza ve uygulamalarımıza olumlu katkı sunacak önemli veriler barındırmaktadır. Bu açıdan Müslümanların çağdaş eğitim karşısında yaşadığı bazı uyumsuzlukların ve krizlerin aşılması için İslâm eğitim geleneğini farklı bakış açılarıyla ve farklı boyutlarıyla değerlendiren çalışmalar yapılmalıdır. İslâm eğitim anlayışını incelerken uygulamaların ve bu anlayışın beslendiği teorilerin birlikte öncelenmesi, bazı olumsuz uygulamaların İslâm eğitim anlayışını yansıttığını düşünme hatasını ortadan kaldırabilecektir. Bu açıdan İslâm eğitim geleneğinin/anlayışının "ne" olduğunu anlama sürecinde, İslâm medeniyetinin hem gömülü olan hem de aşikâr olan ilke ve teorilerinden hareket ederek bu anlayışı yeniden ifade etmeye çalışmak araştırmacıların ilk amaçları arasında olmalıdır.

Funding / Finansman: This research received no external funding. / Bu araştırma herhangi bir dış fon almamıştır.

Conflicts of Interest / Çıkar Çatışması: The author declare no conflict of interest. / Yazar, herhangi bir çıkar çatışması olmadığını beyan eder.

\section{Kaynakça}

Arjmand, Reza. “Islamic Education: Historical Perspective, Origin, and Foundation". PDF: Springer International Publishing. Handbook Of Islamic Education, ed. H. Daun vd.. 332. International Handbooks of Religion and Education 7, 2018. Https://Doi.Org/10.1007/978-3-319-64683-1_3

Atay, Hüseyin. "Bilgi Teorisi (İlmin İmkânı)". Ankara Üniversitesi Illahiyat Fakültesi Dergisi 29/1 (1987), 1-39. DOI: 10.1501/Ilhfak_0000000630

Bardakoğlu, Ali. "Açılış Konferansı". Gelenek ve Modernite Arasında İslâm Yorumları, ed. Murat Ak \& Hasan Cansız 21-42. Konya: NEÜ Yayınları, 2017.

Bauer, Thomas. Müphemlik Kültürü ve İslâm. çev. Tanıl Bora. İstanbul: İletişim Yayınları, 2019.

Berkey, Jonathan. P. Ortaçağ Kahire'sinde Bilginin İntikali. çev. İsmail Eriş. İstanbul: Klasik Yayınları, 2015.

Câbirî, Muhammed Abid. Arap-İslâm Aklının Oluşumu. çev. İbrahim Akbaba. İstanbul: Kitabevi Yayınları, 2001.

Chamberlain, Michael. Ortaçağ'da Bilgi ve Sosyal Pratik: Şam 1190-1350. çev. Büşra Kaya. İstanbul: Klasik Yayınları, 2014. 
Dodge, Bayard. Muslim Education in Medival Times. Washington: The Middle East Institute, 1962.

Furat, Ayşe Zişan. "Medreselerden Tanzimat'a Kadar Eğitim ve Din Eğitimi”. Din Eğitimi, ed. İbrahim Turan vd.. 73-89. Ankara: Bilay Yayınları, 2020.

Gözütok, Şakir. İslâm Medeniyetinde Eğitim Felsefesi. İstanbul: Ensar Yayınları, 2019.

Gündoğdu, Cengiz. "XVII. Yüzyıl Osmanlısında Siyasi Otoritenin Ulema-Sufi Yaklașımına Dair Bir Örnek, IV. Murat-Kadızade-Sivasi”. Dini Araştırmalar, 2/5 (1999), 203-223.

Gürdal Tamdoğan, Oya. "Bilgi Toplumu Geçitinde Bilgi ve/veya Bilgilenim Kültürü", Ankara Üniversitesi Dil ve Tarih-Coğrafya Fakültesi Bilgi ve Belge Yönetimi Bölümü'nün Kuruluşunun 50. Yılına Armağan, Haz. Doğan Atılgan, 51-64 Ankara: Ankara Üniversitesi DTCF Bilgi ve Belge Yönetimi Bölümü, 2004.

Hallaq, Wael B. Şarkiyatçılı̆̆ı Yeniden Düşünmek: Modern Bilginin Eleștirisi. İstanbul: Ketebe Yayınları, 2020.

Halstead, J. Mark. "An Islamic Concept Of Education”. Comparative Education 4/4 (2004), 517-529.

İbn Cemâa, B. Sa'dullah. Tezkiratü's-Sami' ve'l-Mütekellim fi Edebi'l-Âlim ve'l-Müteallim. çev. M. Şevki Aydın. İstanbul: Marifet Yayınları, 1998.

İbn Haldûn. Mukaddime. çev. Halil Kendir. 2. Cilt. İstanbul: Yeni Şafak Kültür Yayınları, 2004.

İbn Rüşd. Siyasete Dair Temel Bilgiler. çev. Muharrem Hilmi Özer. İstanbul: Bordo- Siyah Yayınları, 2005.

İpek, Fatih. (2017). “İbn Rüşd'ün Platon'un “Devleti” ne Yaptığı Şerh Bağlamında Evrensel Felsefi Mirasta İslâm Felsefesinin Yeri". Medeniyet ve Birlikte Yaşama Kültürü Sempozyumu Bildiri Kitabı. ed. Muhiddin Okumuşlar \& Ertan Özensel. 119-135, 2017. Http://Udakb.Timav.Com.Tr/3_Sempozyum_Kitabi.Pdf

Kâbisi, Ebu'l Hasan Ali B. Muhammed B. Halef. Er-Risalatu'l- Mufassalla Li Ahvali'ilMuta'allim Ve Ahkâmi'l Muâllimin ve'l Müte'âllimin -İslâmda Öğretmen ve Öğrenci Meselelerine Dair Geniş Bir Risale-. çev. Süleyman Ateş \& Hıfzurrahman R. Öymen. Ankara: Ankara Üniversitesi İlahiyat Fakültesi Yayınları, 1966.

Kutluer, İlhan. "İslâm'da Bilgi Kaynağı Olarak Akıl”. İslâm'a Giriș: Ana Konulara Yeni Yaklaşımlar, ed. Bünyamin Erul, 41-53. Ankara: Diyanet İşleri Başkanlığı Yayınları, 2006.

Lewis, Bernard. Hata Neredeydi? Doğu'nun 300 Yıldır Cevabını Aradığı Soru. çev. M. Murtaza Özeren. İstanbul: Kronik Yayınları, 2020.

Makdisi, George. İslâm'ın Klasik Çağında Din, Hukuk, Eğitim. çev. Tuncay Başoğlu. İstanbul: Klasik Yayınları, 2007.

Makdisi, George. Ortaçağ’da Yükseköğretim. Çev. A. Hakan Çavuşoğlu \& Tuncay Başoğlu. İstanbul: Klasik Yayınları, 2012.

Meydan, Hasan. "Doktriner Düşünce ve Din Eğitimi: Anlamlı Öğrenme ve Bireysel Manevi Tecrübe Bağlamında Bir Değerlendirme". Ondokuz Mayıs Üniversitesi İlahiyat Fakültesi Dergisi 40 (2016), 85-114.

Sahin, Abdullah. New Directions in Islamic Education: Pedagogy and Identity Formation. Leicestershire: Kube Academic Publishing, 2013.

Stewart, Devin J. "Memlük Mısır'ı ve Suriyesi'nde Fıkıh Doktorası”. İslâmın Klasik Çağında Hukuk ve Eğitim: George Makdisi Anısına. Ed. Joseph E. Lowry vd.. 33-97. İstanbul: Klasik Yayınları, 2019.

Üzüm, İlyas. "Sünnilikten Şiiliğe, Şiilikten Sünniliğe Geçen İki Müellif ve Eserleri”. İslâmi Araştırmalar Dergisi 1 (1997), 189-202.

Tan, Charlene. Islamic Education and Indoctrination: The Case in Indonesia. New-York: Routledge, 2011.

Tan, Charlene. "Introduction". Reforms in Islamic Education: International Perspectives. London \& New-York: Bloomsbury Academic, 2015.

Watt, William M. Müslüman Aydın Gazâlî Hakkında Bir Araştırma. çev. Hanifi Özcan. Ankara: Ankara Okulu Yayınları, 2017.

Weiss, Bernard. “Ortaçağ’da Fıkıh Eğitimi: Seyfeddin El-Âmîdî’nin Eserlerine Yansıdığı 
Şekliyle”. İslâmın Klasik Çă̆ında Hukuk ve Eğitim: George Makdisi Anısına. ed. Joseph E. Lowry, vd.. 123-147. İstanbul: Klasik Yayınları, 2019.

Zernûci, Burhaneddin. Tâ'lim'ül Müteallim. Çev. Y. Vehbi Yavuz. İstanbul: Sahhaflar Kitap, 1989. 